\title{
AGRICULTURAL DEVELOPMENT AND MODERNIZATION IN SOUTH ASIA
}

Hiroyuki Takeshima, Anjani Kumar, Akhter U. Ahmed, and P. K. Joshi

Agriculture, natural resources, and the nutrition landscape in South Asia (SA) are unique. As in other Asian regions, SA's agriculture is largely smallholder based and continues to employ a large share of the workforce, compared with Latin America. Compared with Africa south of the Sahara (SSA), agricultural modernization and intensification in SA have progressed more substantially. However, compared with East Asia (that is, Northeast and Southeast Asia), the speed of agricultural transformation has remained slower in terms of the exit of labor from farming, despite comparable intensification levels. The region is still home to almost 300 million of the poor, a majority of whom live in rural areas, engaging in agriculture. SA is also one of the regions with the scarcest natural resource endowments per capita, including water resources. ${ }^{1}$ Finally, the multiple burden of malnutrition persists, as the region remains one of the largest contributors to global undernutrition, while simultaneously overnutrition continues to emerge (Meenaksh 2016). Therefore, in SA, understanding the evolution and implications of agricultural development is important particularly in the context of agricultural transformation, natural resource management, poverty, and food/nutrition security improvement.

Research in the agricultural economics field has shed important light on various aspects of agricultural development patterns in the last few decades in the region, ranging from productivity growth, changes in resource endowments, intensification/modernization, urbanization and nutritional transition, and their drivers as well as inhibitors. The contribution of this chapter is to provide, through the review of productivity growth patterns and seminal papers in the literature, narratives of how these aspects may be interconnected in terms of their collective implications for the challenges and opportunities of future agricultural development in SA.

1 Renewable internal freshwater per capita in SA is greater than that of only the Middle East and North Africa and is a fraction of the resources of East Asia and the Pacific, SSA, or Latin America (World Bank 2018). 
The second section of this chapter highlights that labor productivity (which is closely related to returns to labor) seems inherently low in SA and that agriculture seems to have contributed to income growth through land productivity growth. But the region may be approaching a point where further growth must come from greater labor productivity growth rather than land productivity growth. We explore this issue by examining the changes in labor and land productivity growth, as well as the land-labor ratio. The third section highlights that, in SA, because of low-income status and limited resources for food imports, domestic production remains an important source of food for consumers. Demand for diversification and improved nutritional intake might have been and may continue to be met by diversification in agricultural production in the region, while growing exportable high-value agricultural products may induce some specialization.

The fourth section then discusses key technological and institutional innovations, emerging rural employment as well as challenges, and growing inefficiency of small farms, with potential implications for the future labor productivity increase in SA. The section highlights innovations in technologies and institutions that have emerged, and related policies. Growing evidence of the inefficiency of small farms is reviewed. Emerging rural employment growth patterns, where the agricultural sector continues to be dominant but the nonfarm sector, such as the garment sector, is gradually expanding as a source of employment, are also discussed for their implications for labor productivity. It also touches on some inequality issues that are associated.

The last section summarizes the main messages and discusses some forward-looking emerging issues.

\section{A Review of Productivity Growth in Agriculture}

This section reviews the key patterns of agricultural productivity growth in SA, important aspects of the growth patterns of total factor productivity (TFP), and changes in natural resource endowments. The section aims to show that the past labor productivity growth in SA has been associated largely with the growth in land productivity, although TFP growth, particularly since the 1980s, has contributed to it as well. The section also shows that natural resource endowments in SA (water, soil, land) have been gradually eroded, potentially limiting substantial future land productivity growth in the region. 


\section{Factor Endowments and Partial Productivity Growth}

This section extends analyses by Hayami and Ruttan (1985, Chapter 5) of factor endowments and partial productivity growth, focusing on key SA countries. Table 4.1 summarizes the changes in partial productivity of land and labor, as well as land-labor ratios, in seven SA countries from the 1960 s to 2010s. This table corresponds to Table 5-1 in Hayami and Ruttan (1985). Figure 4.1 then plots the labor and land productivity for the seven countries presented in Table 4.1, corresponding to Figure 5-1 in Hayami and Ruttan (1985). To highlight the differences between SA and East Asia, which were analyzed in Chapter 3, Figure 4.1 also plots trajectories for East Asian countries (countries shown without labels). Table 4.1 and Figure 4.1 can be interpreted in the following way: many countries from the 1960s to the 2010s exhibited slopes that were steeper than the uni- $A / L$ lines (dotted lines in Figure 4.1 along which agricultural output per agricultural land $([A])$ and agricultural output per worker $([L])$ change at the same proportions), indicating that increases in labor productivity were smaller than those in land productivity. Afghanistan and Bhutan even had absolute declines in labor productivity during these periods. While Bangladesh has been an exception, labor productivity growth has been only marginally higher than land productivity growth. Even in Pakistan, where land per labor has been historically high, the recent trend has exhibited greater land productivity growth than labor productivity growth. These patterns suggest that increases in land productivity also contributed to the increase in labor productivity between the 1960s and 2010s. Few of these countries have experienced growth paths that were more toward greater labor-productivity improvement than land-productivity improvement, which many higher-income countries have experienced. However, shifts from paths steeper than the uni- $A / L$ line to paths that are parallel to it, which Bangladesh has experienced, suggest that those countries have managed to move out of the conditions prevalent in earlier periods, when high growth rates of the labor force in agriculture largely eroded the gains in labor productivity growth arising from land productivity growth.

Comparisons between SA countries and East Asian countries suggest that the trajectories of many SA countries are similar to those of East Asia, with SA lagging behind rather than following a different path. The differences between SA and East Asia might have been due to factors that have led to slower growth in human capital and land quality in SA, such as education and irrigation, as described in more detail in the later section. 
TABLE 4.1 Estimates of land and labor productivity and endowments in agriculture, South Asian countries, 1960s-2010s

\begin{tabular}{lcccccc}
\hline & 1960 s & 1970s & 1980s & 1990s & 2000s & 2010s \\
\cline { 2 - 7 } Country & \multicolumn{5}{c}{ Labor productivity (Y/L) } \\
\hline Afghanistan & 756 & 782 & 818 & 755 & 624 & 626 \\
Bangladesh & 348 & 339 & 348 & 377 & 527 & 714 \\
Bhutan & 655 & 614 & 631 & 722 & 563 & 460 \\
India & 453 & 492 & 562 & 669 & 752 & 928 \\
Nepal & 335 & 345 & 392 & 460 & 468 & 515 \\
Pakistan & 868 & 972 & 1132 & 1521 & 1554 & 1554 \\
Sri Lanka & 561 & 584 & 650 & 617 & 644 & 758 \\
\hline & & & Land productivity (Y/A) & & \\
\hline Afghanistan & 137 & 158 & 144 & 159 & 183 & 222 \\
Bangladesh & 698 & 681 & 724 & 751 & 949 & 1199 \\
Bhutan & 361 & 362 & 396 & 452 & 598 & 748 \\
India & 289 & 335 & 417 & 539 & 632 & 817 \\
Nepal & 646 & 600 & 583 & 716 & 901 & 1154 \\
Pakistan & 148 & 193 & 260 & 380 & 477 & 553 \\
Sri Lanka & 525 & 594 & 716 & 718 & 788 & 878 \\
\hline & & & Land per labor (A/L) & & \\
\hline Afghanistan & 5.54 & 4.95 & 5.73 & 4.84 & 3.44 & 2.82 \\
Bangladesh & 0.50 & 0.50 & 0.48 & 0.50 & 0.55 & 0.60 \\
Bhutan & 1.82 & 1.70 & 1.60 & 1.60 & 0.96 & 0.61 \\
India & 1.57 & 1.47 & 1.35 & 1.24 & 1.19 & 1.14 \\
Nepal & 0.52 & 0.58 & 0.67 & 0.64 & 0.52 & 0.45 \\
Pakistan & 5.86 & 5.05 & 4.37 & 4.01 & 3.27 & 2.81 \\
Sri Lanka & 1.07 & 0.99 & 0.91 & 0.86 & 0.82 & 0.86 \\
\hline & & & & & \\
\hline
\end{tabular}

Source: Authors' calculations based on data from USDA (2020).

Table 4.2 summarizes the growth rates of labor productivity and land productivity, and the land-labor ratio of the 1960s, 1980s, and 2010s. This table corresponds to Table 5-2 of Hayami and Ruttan (1985). There is some intraregion diversity in productivity growth and the changes in factor endowments. Land productivity $(Y / L)$ has exhibited some convergence, in which countries with low initial levels (India and Pakistan) have experienced faster growth compared with countries with higher initial levels (Bangladesh, Sri Lanka). On the other hand, signs of convergence are much weaker for labor productivity. Although Pakistan, with the highest labor productivity, experienced 
FIGURE 4.1 Labor and land productivity growth in agriculture in South Asia in comparison to East Asia

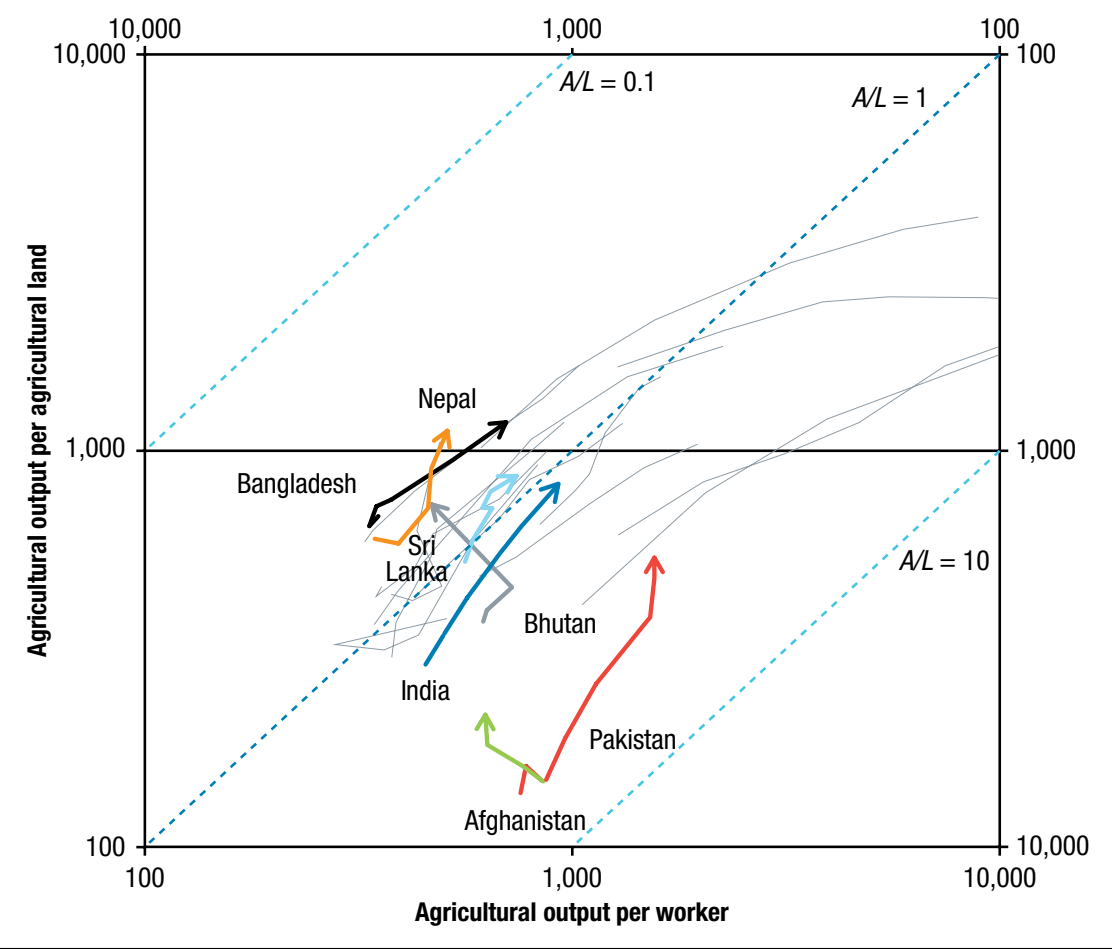

Source: Authors' calculations based on Table 4.1 for South Asian countries and Chapter 3 of this book for East Asian countries. Note: Gray lines indicate the trajectories of countries in East Asia.

lower growth rates than other countries in the 2000s and 2010s, its growth rate had been high up to the 1990s. In contrast, Nepal and Sri Lanka, whose labor productivity was lower in the 1960s, have seen slower growth rates up to the 2010s.

While land-labor ratios have remained relatively constant in Bangladesh, Nepal, and Sri Lanka from the 1960s to the 2010s, those in India and Pakistan have declined more sharply. Because of this pattern, labor productivity growth in India and Pakistan has been much lower than the land productivity growth during this period (1.4 and 1.2 percent as opposed to 2.1 and 2.7 percent). The absorption of the growing rural labor force in nonfarm sectors in India and Pakistan has been much slower than in the other three countries in SA. Sri Lanka has experienced particularly slow labor and land productivity growth rates, with labor and land productivity being caught up 
TABLE 4.2 Growth rate (\%/year) of agricultural output per worker (Y/L), agricultural output per hectare $(\mathrm{Y} / \mathrm{A})$, and land-labor ratio $(\mathrm{A} / \mathrm{L})$

\begin{tabular}{|c|c|c|c|c|c|c|c|c|}
\hline Years & & Afghanistan & Bangladesh & Bhutan & India & Nepal & Pakistan & $\begin{array}{c}\text { Sri } \\
\text { Lanka }\end{array}$ \\
\hline 1960s-2010s & $\mathrm{Y} / \mathrm{L}$ & -0.4 & 1.4 & -0.7 & 1.4 & 0.9 & 1.2 & 0.6 \\
\hline 1960s-2010s & Y/A & 1.0 & 1.1 & 1.5 & 2.1 & 1.2 & 2.7 & 1.0 \\
\hline 1960s-2010s & $A / L$ & -1.3 & 0.4 & -2.2 & -0.6 & -0.3 & -1.5 & -0.4 \\
\hline 1960s-1980s & $\mathrm{Y} / \mathrm{L}$ & 0.4 & 0.0 & -0.2 & 1.1 & 0.8 & 1.3 & 0.7 \\
\hline 1960s-1980s & $\mathrm{Y} / \mathrm{A}$ & 0.2 & 0.2 & 0.5 & 1.9 & -0.5 & 2.9 & 1.6 \\
\hline 1960s-1980s & $A / L$ & 0.2 & -0.2 & -0.6 & -0.8 & 1.3 & -1.5 & -0.8 \\
\hline 1980s-2010s & $\mathrm{Y} / \mathrm{L}$ & -0.9 & 2.4 & -1.0 & 1.7 & 0.9 & 1.1 & 0.5 \\
\hline 1980s-2010s & $\mathrm{Y} / \mathrm{A}$ & 1.5 & 1.7 & 2.1 & 2.3 & 2.3 & 2.5 & 0.7 \\
\hline 1980s-2010s & $A / L$ & -2.3 & 0.7 & -3.2 & -0.6 & -1.3 & -1.5 & -0.2 \\
\hline
\end{tabular}

Source: Author's compilations based on Table 4.1.

by Bangladesh (labor productivity) and India or Nepal (land productivity) by the 2010s. The slow productivity growth in Sri Lanka in the last three decades has been partly due to the slow output growth rates of nonrice commodities that have accounted for about two-thirds of total outputs, including vegetables and fruits (plantains, etc.), tea, coconuts, and rubber (these are discussed more at the beginning of the third section).

Figure 4.2 and Figure 4.3 illustrate the changing relationship between the land-labor ratio and tractor horsepower (HP) per worker, and between land productivity and fertilizer input per hectare, corresponding to Figures 5-3 and 5-4 in Hayami and Ruttan (1985). These figures illustrate the agricultural growth process that involves the substitution of man-made inputs for labor and land. Fertilizer and tractor HP are used as proxies for the factors that substitute for land and labor, respectively.

Most SA countries have seen substantial increases in tractor HP per worker, without increases in land-labor ratios in the past five decades (Figure 4.2). In some countries, like India and Pakistan, the land-labor ratios have declined alongside the increase in tractor HP per worker. These patterns are, however, still consistent with Hayami and Ruttan (1985). In Hayami and Ruttan (1985, Figure 5-3), at a lower level of tractor HP per male worker, land-labor ratios are generally flat. Once it exceeds a threshold, the increase in tractor HP per male worker becomes increasingly more positively associated with the land-labor ratio. In the past five decades, while tractor HP per 
FIGURE 4.2 Comparison of land-labor ratio and tractor horsepower per worker, with arrows connecting data points for decade averages from the 1960s to 2010s

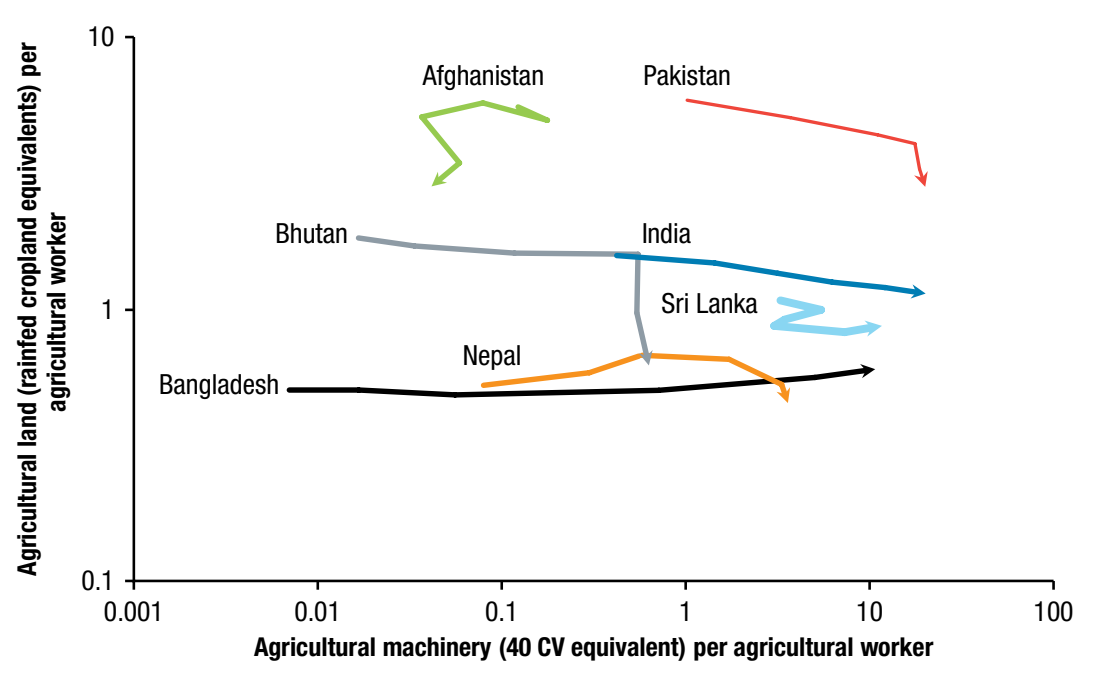

Source: Authors' calculations and FAO (2020a).

Note: CV (chevaux vapeur), used in FAO (2020a), is a unit of metric horsepower (HP), approximately equivalent to mechanical horsepower. CV is assumed to be 10 and 40 on average for two-wheel tractors (2wt) and four-wheel tractors (4wt), respectively, unless otherwise stated. Importantly, however, average tractor CV has generally increased over time, and ignoring that trend could underestimate the overall trend of tractor CV growth. For Bangladesh and India, interpolation used a constant growth rate (not linear). For Nepal, FAO figures seem to closely match with other sources and therefore FAOSTAT figures were used for 4wt. For 2wt, interpolation used a constant growth rate (not linear); there were also around 1,000 minitillers in 2010, but they were excluded. For Pakistan, several studies indicate CV to be slightly higher than 40 . Also, information about 2 wt in Pakistan has been very difficult to obtain. Therefore, the tractor CVs used for Pakistan are more conservative estimates. For Sri Lanka, information about 4wt has been relatively limited. Therefore, the growth rate between 1980 and 2002 for which information is available was applied to extrapolate the growth from 2002.

worker has increased considerably in SA countries, its level still has been too low to translate into significant increases in land-labor ratios. However, by the 2010s, many countries had reached the threshold of tractor HP per worker. Therefore, these countries are expected to see growth of the land-labor ratio as tractor HP per worker further increases in the future. As shown in the fourth section, tractor usage for land preparation has reached almost 100 percent in most SA countries (except Nepal), primarily through tractor rentals. Therefore, further increases in tractor HP per worker may accompany substantial reductions in the absolute number of agricultural workers.

Figure 4.3 illustrates the process where constraints in agricultural production due to land resource endowments have been mitigated through the increased use of fertilizer (and other yield-enhancing inputs) per unit of land. Figure 4.3 suggests that many SA countries have seen clearer trends in this aspect of land-constraint mitigation as indicated by strongly positive 
FIGURE 4.3 Comparison of land productivity and fertilizer input per hectare, with arrows connecting data points for decade averages from the 1960s to 2010s

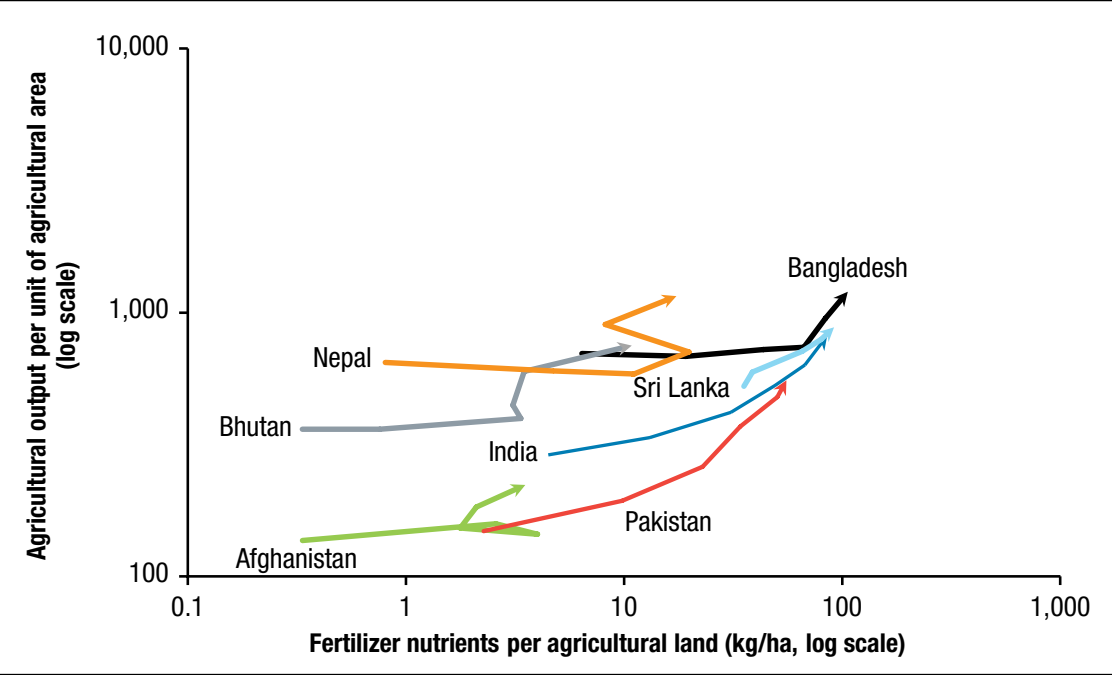

Source: Data from FAO (2020a).

Note: Fertilizer nutrients = the sum of the quantities of three major nutrients: nitrogen, phosphate, and potassium.

slopes. These patterns seem to have become reinforced since the 1980s. It is interesting to note that curves are convex rather than concave, which indicates that decreasing marginal productivity of fertilizer is more than offset by fertilizer-using technological changes. This is similar to the pattern observed in East Asia.

Altogether, the investigations of factor endowments, land and labor productivity growths, and the trends in the land- and labor-substituting input uses have revealed that SA still follows the agricultural growth trajectory hypothesized for land-scarce countries by Hayami and Ruttan (1985). Pre1980 s had been characterized by modest land productivity growth and fairly small labor productivity growth due to the growth of the number of agricultural workers relative to land. However, since the 1980s, the land-labor ratio has become relatively constant and the continuous growth of land productivity seems to have largely translated into the increase in labor productivity. The land productivity growth might have been primarily led by land-saving inputs like fertilizer and other yield-enhancing inputs. The use of power and machinery has continued growing, and SA seems to have reached the point where further increases in power and machinery use per worker may be associated with a significant increase in the land-labor ratio. 


\section{Total Factor Productivity Growth}

Key evidence on agricultural TFP growth in SA countries is mostly provided in the literature as part of TFP analyses for a larger set of countries. For SA as a whole, TFP growth had been lower between the 1960s and mid-1980s and turned upward since the mid-1980s, although it has been generally lower than in most other regions throughout the periods since the 1960s, largely due to the slow efficiency growth (despite comparable technical improvements), including the post-1980s period (Nin-Pratt and Yu 2010). TFP growth between 1965 and 1996 was also lower than in East Asia, due to slower efficiency growth (Suhariyanto and Thirtle 2001). Both studies, however, also suggest that since the 1980s, technical changes in SA have been faster than in other parts of Asia, while slower growths of TFP in SA during the last several decades have been largely due to slower technological progress.

Coelli and Rao (2005) suggest substantial variations in TFP growth rates within SA between 1980 and 2000. During this period, Bangladesh and Pakistan observed the highest TFP growth, India and Nepal saw medium TFP growth, and Sri Lanka saw the lowest growth.

More detailed country-level investigations reveal spatial, regional, and temporal variations. In Indian Punjab, TFP growth would have been considerably higher, about 3 percent per year during the Green Revolution era (1966-1975) compared with 1 to 2 percent per year in the post-Green Revolution era (1986-1994) (Murgai 2001). TFP growth in the Indo-Gangetic Plain (IGP) region of India was 1.2 percent per year from 1981 to 1996, with more impressive TFP growth during the 1980s than in the 1990s (Kumar, Kumar, and Mittal 2004). TFP growth seems to have been particularly high in early periods. This is potentially because the shift from traditional varieties to modern high-yielding varieties (HYVs), compared with subsequent shifts from the original Green Revolution varieties to the second- and third-generation varieties, might have been much more drastic in terms of the technological progress. Lower TFP growth in the post-Green Revolution era might have been partly due to land quality, including depletion/pollution of groundwater resources, a buildup of soil salinity and waterlogging, nutrient mining, micronutrient deficiencies, deteriorating water quality, the formation of subsoil compaction, and increased pest buildup (Kumar, Kumar, and Mittal 2004). The development of roads and investment in irrigation infrastructure had positive causal effects on TFP growth in rural India between 1971 and 1994 (Zhang and Fan 2004).

In India, the TFP level has remained diverse across states (Mukherjee and Kuroda 2003). The TFP growth rates have also varied across regions and over 
time (Rada 2016), reflecting important dynamics. Since the 1980s, the northern, eastern, central, and northeastern regions have still grown the fastest, due to the remaining effects of the aforementioned Green Revolution technologies. The western and southern regions experienced more rapid growth since the 2000s - partly contributing to their catching up. Rada (2016) speculates that these patterns have been associated with shifts away from grains (commonly grown in the north) to higher-value crops including horticulture and livestock products. Meanwhile, the northern and eastern regions also saw recovery in TFP growth in the 2000s. This had been partly through reduced water use intensity enabled by investments in efficient irrigation methods, including drip irrigation (Rada 2016), which partly mitigated the overexploitation of groundwater in these regions, as described in a later subsection. In the northeastern region, deficiencies in transportation and market infrastructure, among others, relatively suppressed TFP growth even during this period (Rada 2016).

Similarly, in Bangladesh the TFP growth between 1948 and 2008 exhibited heterogeneity across regions (Rahman and Salim 2013). Growth had been the fastest in Chittagong (largely due to technical-efficiency gains and some scale-efficiency change). It had been slow in the Chittagong Hill Tracts, largely due to inefficiency in exploiting economies of scope in production achievable through diversifying into the production of crops suitable for hilly environments. According to Rahman and Salim (2013), regional variations in the efficiency in exploiting economies of scope explain significant variations in TFP growth across Bangladesh.

\section{Changes in Natural Resources (Water, Soil)}

The productivity gains in SA agriculture might have been achieved at the cost of key natural resource endowments, including soil (land degradation) and water. Such a decline in natural resource endowments suggests that future land productivity growth in SA faces considerable challenges.

FAO (1994) suggests that by the 1990s, land degradation in SA had intensified primarily through erosion of soils by water and wind, the decline of soil fertility, and deterioration of soil quality through waterlogging or salinization, among others. These conditions are likely to have remained since then. FAO (1994) estimates that by the early 1990s, 25 percent of areas under crop and pasture in SA had been affected by water erosion (Table 4.3). ${ }^{2}$ More than

2 The figures were estimated based on the map created by the global assessment of soil degradation (GLASOD) project conducted by the International Soils Research and Information Centre (ISRIC), as well as secondary sources including government reports (FAO 1994). 
TABLE 4.3 Share (\%) of areas under crop and pasture affected by different types of land degradation, early $1990 \mathrm{~s}$

\begin{tabular}{lccccc}
\hline Country & Water erosion & Wind erosion & $\begin{array}{c}\text { Soil fertility } \\
\text { decline }\end{array}$ & Water logging & Salinization \\
\hline Afghanistan & 29 & 5 & 0 & 0 & 3 \\
Bangladesh & 15 & 0 & 65 & 0 & 0 \\
Bhutan & 10 & 0 & 0 & 0 & 0 \\
India & 18 & 6 & 2 & 2 & 2 \\
Nepal & 34 & 0 & 0 & 0 & 0 \\
Pakistan & 28 & 42 & 0 & 4 & 15 \\
Sri Lanka & 46 & 0 & 61 & 0 & 2 \\
Region & 25 & 18 & 3 & 1 & 13 \\
\hline
\end{tabular}

Source: Data from FAO (1994).

half of the land in Bangladesh and Sri Lanka had suffered soil fertility decline. More than one-third of the areas were affected by different types of land degradation in different countries. Land degradation has become costly in SA. The estimated economic losses due to land degradation in SA by the 1990s were US $\$ 5.4$ billion from water erosion, $\$ 1.8$ billion from wind erosion, $\$ 0.6-$ 1.2 billion from soil fertility decline, $\$ 0.5$ billion from waterlogging, and $\$ 1.5$ billion from salinization - the total being equivalent to 7 percent of agricultural gross domestic product (GDP) then (FAO 1994).

$\mathrm{SA}$, which is the most water-scarce region in the world, has also suffered from a declining groundwater table lately. Since 1960, SA has used the most groundwater in the world, and this pattern has accelerated since the 1990s (Shah et al. 2009). Combined with the rising pumping costs due to rising diesel prices, the lowering of the groundwater table has further raised irrigation costs, particularly in the IGP. This has lately led farmers to shift from more water-intensive crops to less water-intensive crops or to rainfed farming systems (Shah et al. 2009).

\section{Agricultural Growth, Urbanization, and Nutritional Transition}

This section describes the key characteristics of agricultural growth, patterns of urbanization, and nutritional transitions in SA, with the aim of highlighting how they may be interlinked with each other, creating unique challenges and opportunities for further agricultural development and food and nutrition security improvements in the region. 


\section{Agricultural Growth}

Unique agricultural growth patterns in SA can be highlighted by the analyses of the growth patterns of value-added, modernization, linkages with domestic and international markets, and diversifications.

\section{GROWTH OF AGRICULTURAL VALUE-ADDED}

Agricultural value-added in SA has increased steadily in the past several decades, and the analysis of its growth patterns in comparison with other regions like East Asia or SSA reveals important differences in underlying conditions. The growth rates of agricultural value-added in SA have been 3.2 percent in the past three decades starting in 1985, higher than the rate of 2.4 percent between 1961 and 1985 (Table 4.4). Such acceleration in growth is consistent with the TFP growth patterns described (Nin-Pratt and Yu 2010) in the previous section.

However, the growth rate may have been somewhat slower than in East Asia during both periods. This relatively low growth rate of value-added in SA is consistent with the slow labor productivity growth discussed earlier. This is related to persistently high shares of the workforce being employed in the agricultural sector in many SA countries, except in Sri Lanka. While the share has constantly declined in SA in the past three decades (from 62 percent in 1991 to 44 percent in 2017), the speed had been slower than the pace in East Asia, where the share declined from 55 percent in 1991 to 29 percent in 2017 (Table 4.4). While the agricultural sector in SA has undergone substantial modernization in the past few decades, as described in the next section, such modernization might have remained labor-intensive. In other words, SA seems to have been slow in transforming the economic structure away from agriculture.

\section{MODERNIZATION}

Modernization of agriculture in SA is pronounced in terms of increased adoptions of modern varieties and increased modern inputs use, including chemical fertilizer, machines, and agrochemicals, as well as more systematic uses of water through irrigation (Figure 4.4), although, as is discussed later, use of irrigation on major crops like rice in SA has lagged behind East Asia. Chemical fertilizer use intensity grew substantially up to the 1980s, and it kept growing afterward. By the 2000s, most countries exceeded the intensity of 100 kilograms of nutrients per hectare. The shares of cultivated areas prepared by tractors and irrigated areas have varied more widely across the countries than fertilizer use. Pakistan, Sri Lanka, and India led the growth of tractor uses, 
TABLE 4.4 Growth rates of agricultural value-added, and shares of employment in the agricultural sector in South Asian countries

\begin{tabular}{|c|c|c|c|c|c|c|c|c|c|c|c|}
\hline \multirow[b]{3}{*}{ Country/Region } & \multicolumn{8}{|c|}{ Annual growth rates of agricultural value-added (\%) } & \multirow{2}{*}{\multicolumn{3}{|c|}{$\begin{array}{l}\text { Share (\%) of } \\
\text { employment in the } \\
\text { agricultural sector }\end{array}$}} \\
\hline & \multicolumn{2}{|c|}{ Periods } & \multicolumn{6}{|c|}{ Decades } & & & \\
\hline & $\begin{array}{l}\text { Pre- } \\
1985\end{array}$ & 1985 & $\begin{array}{c}1961- \\
1970\end{array}$ & $\begin{array}{c}1971- \\
1980\end{array}$ & $\begin{array}{c}1981- \\
1990\end{array}$ & $\begin{array}{c}1991- \\
2000\end{array}$ & $\begin{array}{c}2001- \\
2010\end{array}$ & 2011 & 1991 & 2005 & 2017 \\
\hline Afghanistan & - & 3.0 & - & - & - & - & 3.9 & 1.8 & 62 & 65 & 62 \\
\hline Bangladesh & 1.7 & 3.4 & 3.2 & -0.1 & 2.4 & 3.0 & 4.2 & 3.4 & 61 & 48 & 41 \\
\hline Bhutan & - & - & - & - & 5.6 & 1.7 & 2.1 & 3.0 & 62 & 63 & 57 \\
\hline India & 2.4 & 3.2 & 2.5 & 1.8 & 3.5 & 2.8 & 3.3 & 2.9 & 63 & 56 & 44 \\
\hline Nepal & 2.1 & 3.0 & 2.9 & 0.2 & 4.6 & 2.5 & 3.3 & 2.7 & 81 & 77 & 73 \\
\hline Pakistan & 3.7 & 3.4 & 5.1 & 2.4 & 4.1 & 4.5 & 2.6 & 2.2 & 48 & 43 & 42 \\
\hline Sri Lanka & 3.3 & 2.3 & 3.5 & 2.4 & 2.9 & 1.7 & 3.0 & 2.8 & 42 & 33 & 27 \\
\hline South Asia & 2.4 & 3.2 & 2.7 & 1.7 & 3.5 & 3.0 & 3.2 & 2.8 & 62 & 54 & 44 \\
\hline East Asia \& Pacific & 4.3 & 3.6 & 4.9 & 2.7 & 5.2 & 3.3 & 3.8 & 3.6 & 55 & 43 & 29 \\
\hline
\end{tabular}

Source: Authors' compilations from World Bank (2018).

Note: Figures for Afghanistan are only from 2003; figures for East Asia and Pacific exclude high-income countries; $-=$ data not available.

FIGURE 4.4 Trends of modern input uses in agriculture in selected South Asian countries

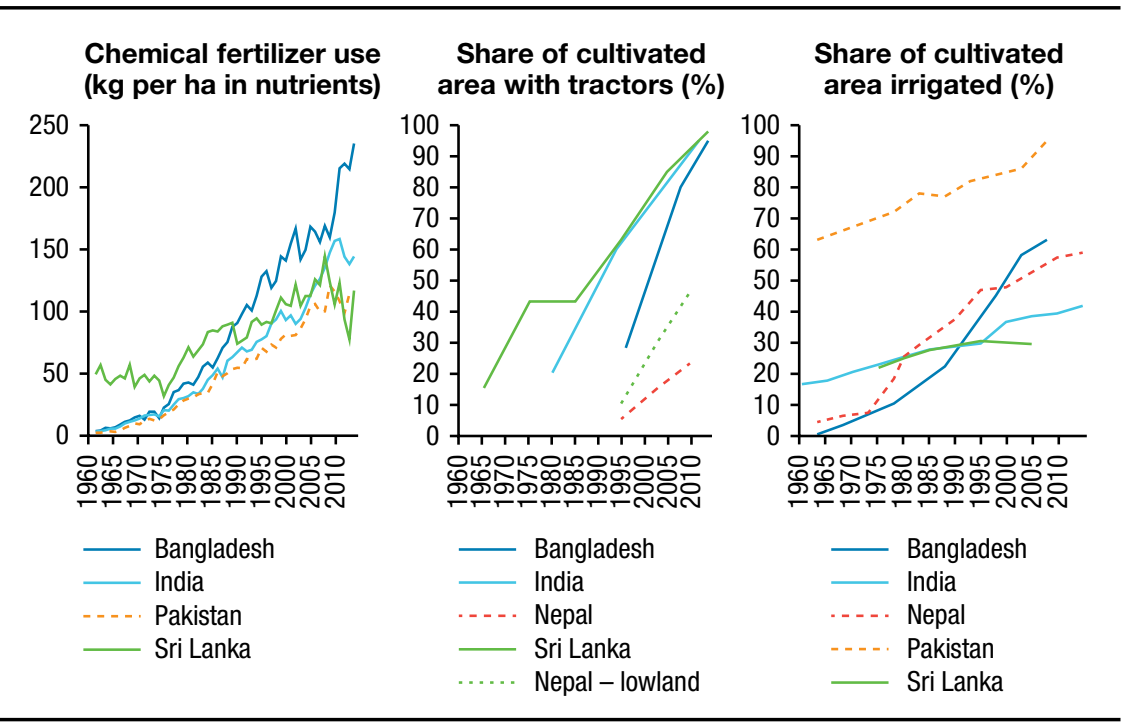

Source: FA0 (2020a) for chemical fertilizer; various other sources for tractor uses and irrigated area shares. 
which have risen continuously since the 1980s. In Bangladesh, tractor use is quickly catching up to other SA countries, mostly through increased use of power tillers. In all four countries, almost all farmland is now prepared by tractors. The tractor use growth in Nepal has been somewhat slower but has grown at comparable speed in the lowland (Terai) zone. Irrigation area coverages have also expanded steadily, in both early adopters, like Pakistan, and late adopters, like Bangladesh and Nepal. Last, the use of agrochemicals (pesticide, herbicide) has also gradually intensified. In India, herbicide use grew 2.5 times between 2005/2006 and 2015/2016, reaching the consumption level of 1 kilogram per hectare (Gupta et al. 2017), which is still considerably lower than in countries like Japan but comparable to use in the United States.

Contrary to the progress in production of staple crops, the modernization of the livestock sector has remained somewhat limited. The dairy sector in SA is still challenged by the limited supply of improved indigenous cattle breeds, limited artificial insemination to provide crossbred cattle, and the generally low quality of crop residue used for most feed resources (McDermott et al. 2010).

Modernization at the postharvest stage has been more heterogeneous, with areas closer to major urban markets experiencing faster modernization. The adoption of modern processing facilities has grown gradually around major urban areas. For example, Bangladesh has seen the emergence of large (automatic) rice mills displacing the traditional small huller mills extensively in parts of the Chittagong Division (Reardon et al. 2012). In the country as a whole, however, the majority of paddy is still processed by traditional mills. Recently, demand has shifted from cheap, coarse rice to higher-value (medium and fine) rice, and there are increasing price premiums for the latter in major urban centers like Dhaka, Bangladesh, accompanied by the growing sales by the modern retail sector (Minten, Murshid, and Reardon 2013). The shift for these modern agrifood systems, however, kept modernization to the postharvest stage, and there was relatively little effect on modernization at the farm level (Minten, Murshid, and Reardon 2013). Similarly, branding by the private sector is still often plagued with incompleteness or misinformation (Minten, Singh, and Sutradhar 2013).

\section{GROWING BUT LIMITED CONTRIBUTIONS OF EXTERNAL TRADE}

Domestic production and consumption seem to continue to be dominant sources of supply and demand for agricultural commodities in SA, despite growing external trade. Table 4.5 shows the shares of the net exported quantities as a percentage of the total quantities domestically produced for each 
group of food commodities (negative values indicate net imports). For example, 12 indicates that the net exports were equivalent to 12 percent of the quantities domestically produced.

Table 4.5 indicates that the quantities of cereals, starchy roots, vegetables, fruits, meat, eggs, milk, and fish products that have been exported or imported have remained fairly small compared with the domestic production of these commodities (generally accounting for 20 percent or less). Only pulses and tree nuts, and other food items that may be relatively minor nutrient sources, have seen substantial increases in the contributions of trade. Generally, domestic productions of key agricultural commodities have remained important sources of domestic food and nutrition, while domestic markets have remained the major drivers of agricultural growth, in SA. This pattern is in contrast to some developing countries in SSA, where the reliance on cereal imports has increased substantially in the past few decades.

\section{DIVERSIFICATION}

$\mathrm{SA}$, as a whole, has seen a gradual decline of the share of cereals, and increasing shares for vegetables, and milk, in net production values (Table 4.6). The trends in India, given its dominant size, largely represent the overall patterns in SA. However, there have been considerable variations and divergence over time across countries outside India (Figure 4.5). In Bangladesh, diversification has been relatively limited, with the share of cereals remaining around 60 percent throughout the past five decades, while the shares of higher-value crops have not changed significantly. ${ }^{3}$ Sri Lanka has actually experienced an increased share of cereals during the last five decades, accompanied by decreasing shares of oil crops, fruits, stimulants (tea in particular), and tobacco/rubber. In contrast, Nepal has seen a rapid shift from cereals and milk to vegetables and fruits and, to a lesser extent, spices. Pakistan, with historically low shares of cereals and higher shares of milk, meat, and fiber crops, has largely maintained the same level of agricultural diversification.

This diversification pattern might have been driven by both the changes in demand and deliberate efforts on the supply side. For example, Sri Lanka had been a major rice importer in the region in the 1960s but has gradually reduced import reliance, partly through the government's effort in achieving

3 It is, however, important to note that this indicator may not capture the important diversifications within each commodity group or crop. For example, Bangladesh has seen a gradual shift from cheap-quality (coarse) rice to more expensive, higher-value (medium and fine) rice over time (Minten, Murshid, and Reardon 2013). 
TABLE 4.5 Share (\%) of net export to domestic production of food commodities

\begin{tabular}{|c|c|c|c|c|c|c|}
\hline \multirow[b]{2}{*}{ Food commodities } & \multicolumn{6}{|c|}{ South Asia excluding India } \\
\hline & $1961-1970$ & $1971-1980$ & $1981-1990$ & 1991-2000 & 2001-2010 & 2011-2013 \\
\hline Cereals, excluding beer & -8 & -12 & -14 & -15 & -11 & -11 \\
\hline Starchy roots & -3 & -1 & -1 & -1 & -1 & 0 \\
\hline Vegetables & -1 & 1 & 0 & 1 & 0 & 1 \\
\hline Fruits, excluding wine & 5 & 4 & 4 & 4 & 2 & 1 \\
\hline Sugar crops & 0 & 0 & 0 & 0 & 0 & 0 \\
\hline Pulses & -5 & -2 & -6 & -13 & -44 & -62 \\
\hline Treenuts & 22 & 18 & 8 & 15 & 5 & -5 \\
\hline Oilcrops & 10 & 5 & 3 & -7 & -22 & -17 \\
\hline Meat & 0 & -4 & -8 & -2 & -2 & -2 \\
\hline Eggs & 0 & -4 & -3 & 0 & 1 & -2 \\
\hline Milk, excluding butter & -2 & -6 & -10 & -3 & -2 & -3 \\
\hline Fish, seafood & -4 & -10 & -15 & -11 & 1 & 2 \\
\hline Aquatic products, other & 0 & 0 & 18 & 75 & 16 & 6 \\
\hline Offals & 0 & 0 & 0 & 0 & 0 & 2 \\
\hline Alcoholic beverages & -11 & -13 & -13 & -8 & 48 & 55 \\
\hline Animal fats & -26 & -38 & -50 & -25 & -16 & -11 \\
\hline Spices & -10 & 1 & -2 & -6 & -15 & -20 \\
\hline Stimulants & 72 & 51 & 33 & 20 & 22 & -5 \\
\hline Sugar and sweeteners & -21 & -18 & -26 & -28 & -49 & -41 \\
\hline Vegetable oils & -25 & -94 & -214 & -268 & -267 & -362 \\
\hline
\end{tabular}

rice self-sufficiency. Another contributing factor might have been the declining real price of rice and other grains, which is likely to have induced a shift of the production toward high-value crops.

Aquaculture production has grown in the last few decades in many SA countries, often 10-fold between the 1980s and the 2010s in gross production value. While the production value is still small compared with the entire agricultural production, it has grown to the equivalent of 20 percent of gross agricultural production in countries like Bangladesh (Table 4.6). The sector has contributed to poverty reduction through reduced price of fish products and their increased consumption by low-income consumers (Toufique and Belton 2014), through improved economic activities of women (Kawarazuka and Béné 2010), and through employment (Paul and Vogl 2011). Its growth has, however, also caused environmental damage, including mangrove 


\begin{tabular}{lrrrrrr} 
& \multicolumn{7}{c}{ India } \\
\cline { 2 - 7 } Food commodities & $1961-1970$ & $1971-1980$ & $1981-1990$ & $1991-2000$ & $2001-2010$ & $2011-2013$ \\
\hline Cereals, excluding beer & -8 & -3 & 0 & 1 & 3 & 8 \\
Starchy roots & 0 & 0 & 0 & 0 & 0 & 0 \\
Vegetables & 1 & 0 & 1 & 1 & 2 & 2 \\
Fruits, excluding wine & -1 & 0 & 0 & 0 & 0 & 0 \\
Sugar crops & 0 & 0 & 0 & 0 & 0 & 0 \\
Pulses & 0 & 0 & -4 & -3 & -16 & -19 \\
Treenuts & 5 & 18 & 18 & -20 & -19 & -42 \\
Oilcrops & -2 & 0 & 0 & 1 & 1 & 2 \\
Meat & 0 & 1 & 2 & 4 & 9 & 20 \\
Eggs & 0 & 0 & 0 & 1 & 3 & 2 \\
Milk, excluding butter & -2 & -1 & -1 & 0 & 1 & 1 \\
Fish, seafood & 3 & 4 & 4 & 6 & 7 & 12 \\
Aquatic products, other & 100 & 35 & 0 & 1 & 44 & 60 \\
Offals & 0 & 0 & 0 & 0 & 1 & 6 \\
Alcoholic beverages & 0 & 0 & 0 & 1 & -2 & 3 \\
Animal fats & -11 & -10 & -5 & 0 & 0 & 1 \\
Spices & 7 & 7 & 6 & 7 & 10 & 16 \\
Stimulants & 53 & 43 & 38 & 34 & 31 & 36 \\
Sugar and sweeteners & 3 & 4 & -2 & -1 & 4 & 7 \\
Vegetable oils & 0 & -17 & -27 & -24 & -70 & -101 \\
\hline
\end{tabular}

Source: Authors' calculations based on FA0 (2020a).

degradation, saltwater intrusion, sedimentation, pollution, and disease outbreaks (Paul and Vogl 2011).

The diversification patterns have also been associated with cross-country variations in productivity growth, particularly the slower growth in Sri Lanka than in other SA countries described earlier. Table 4.7 summarizes the output growth between the 1980s and the 2010s by commodity groups in Sri Lanka and other SA countries. Output growth for vegetables and fruits has been particularly slow in Sri Lanka ( 0.3 percent per year) compared with SA as a whole (3.6 percent per year). In other SA countries like India, Nepal, and Pakistan, while rice output growth rates have been similar to that of Sri Lanka, nonrice commodities have grown by 3 percent or more (for example, milk in India and Pakistan; meat and cotton in Pakistan; meat, vegetables, and fruits in Nepal). In Bangladesh, rice output growth has been faster, at 2.8 percent per year. 
FIGURE 4.5 Share (\%) of total production of commodity groups, by year, in South Asia

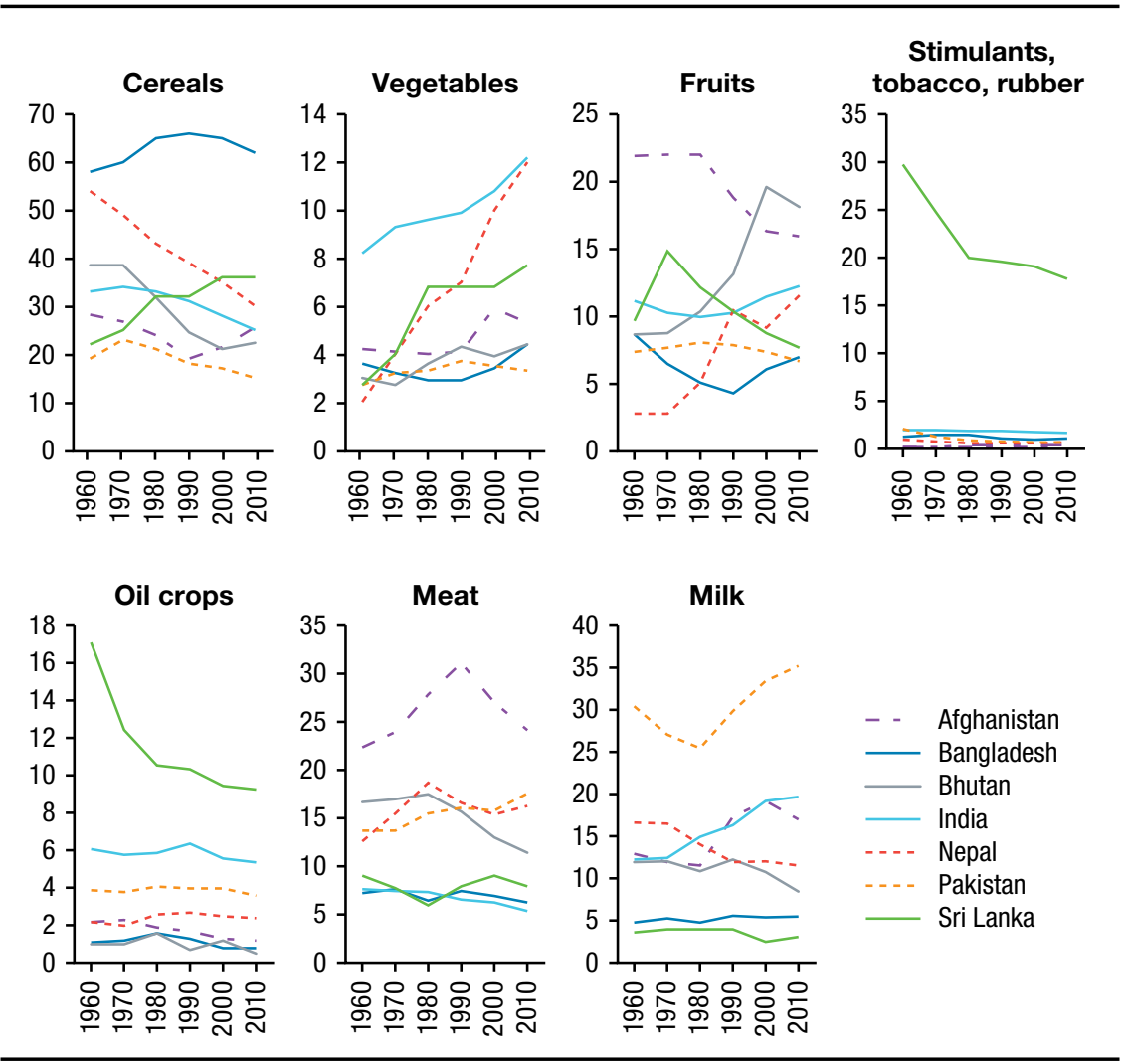

Source: Data from FAO (2020a).

\section{Urbanization}

In relative terms, the pace of urbanization in SA seems to have been slow compared with both growth in the East Asia and Pacific region and the historical experiences of developed countries. Urbanization levels are the lowest in Nepal (19 percent) and Sri Lanka (18 percent), while the Maldives (47 percent), Bhutan (39 percent), and Pakistan (39 percent) are the most urbanized countries in the region (Table 4.8). The urban population accounted for 35 percent in Bangladesh and 33 percent in India. The agricultural growth and modernizations in SA described in the previous section, therefore, seem to have largely taken place in the rural sector.

However, in absolute terms, SA's urban population growth has been and is likely to be significant. The urban population increased from about 
TABLE 4.6 Agricultural diversification patterns in South Asia

\begin{tabular}{|c|c|c|c|c|c|c|}
\hline Groups & $1960 \mathrm{~s}$ & 1970s & 1980s & 1990s & $2000 s$ & 2010s \\
\hline \multicolumn{7}{|c|}{ Share (\%) of production values of each commodity group } \\
\hline Cereals/Country & 33 & 33 & 32 & 30 & 28 & 25 \\
\hline Root crops & 1 & 2 & 2 & 2 & 3 & 3 \\
\hline Pulses & 6 & 5 & 4 & 3 & 3 & 3 \\
\hline Sugar crops & 5 & 5 & 5 & 5 & 4 & 4 \\
\hline Oil crops & 5 & 5 & 5 & 5 & 5 & 5 \\
\hline Vegetables & 7 & 8 & 9 & 9 & 10 & 11 \\
\hline Fruits & 11 & 10 & 11 & 11 & 12 & 12 \\
\hline Meat & 9 & 9 & 9 & 9 & 9 & 8 \\
\hline Milk & 13 & 13 & 15 & 16 & 19 & 19 \\
\hline Others & 10 & 10 & 8 & 10 & 7 & 10 \\
\hline \multicolumn{7}{|c|}{ Aquaculture production value in South Asia (2010 US\$ in thousands) } \\
\hline Bangladesh & - & - & 384,062 & 889,142 & $1,560,988$ & $4,177,766$ \\
\hline Bhutan & - & - & 8 & 54 & 93 & 350 \\
\hline India & - & - & $1,522,334$ & $2,776,292$ & $4,215,351$ & $8,988,443$ \\
\hline Nepal & - & - & 10,219 & 16,084 & 33,740 & 94,732 \\
\hline Pakistan & - & - & 20,645 & 16,849 & 138,071 & 209,918 \\
\hline Sri Lanka & - & - & 4,806 & 37,348 & 37,805 & 51,103 \\
\hline \multicolumn{7}{|c|}{$\begin{array}{l}\text { Proportion of gross aquaculture production to gross agricultural production in values } \\
\text { (agricultural production value }=100 \text { ) }\end{array}$} \\
\hline Bangladesh & - & - & 5 & 10 & 12 & 20 \\
\hline Bhutan & - & - & 0 & 0 & 0 & 0 \\
\hline India & - & - & 1 & 2 & 2 & 4 \\
\hline Nepal & - & - & 1 & 1 & 1 & 2 \\
\hline Pakistan & - & - & 0 & 0 & 1 & 1 \\
\hline Sri Lanka & - & - & 0 & 2 & 2 & 2 \\
\hline
\end{tabular}

Source: Authors' calculations based on FAO (2020a), FAO (2019) for aquaculture production values, and FA0 (2020a) for commodity groups.

Note: Gross aquaculture production value does not include capture fishery. The "proportion" simply compares the sizes and does not mean the share of aquaculture production to agricultural production, since the latter figure does not include the former. $-=$ data not available.

390 million in 2001 to 590 million in 2016-an addition of 200 millionand is expected to expand by almost 250 million more in the next 10 years (Table 4.8). Urbanization still has been one of the drivers of dietary diversifications in SA in recent years (Joshi, Gulati, and Cummings 2007).

Urbanization might have also posed certain challenges to food security. The 2007-2008 food crisis demonstrated the vulnerability of urban 
TABLE 4.7 Growth of outputs by major commodity groups in South Asian countries, 1980s-2010s

\begin{tabular}{|c|c|c|c|c|c|c|}
\hline \multirow[b]{2}{*}{ Country } & \multicolumn{4}{|c|}{$\begin{array}{l}\text { Annual growth rates, } \\
\text { 1980s-2010s (\%) }\end{array}$} & \multicolumn{2}{|c|}{$\begin{array}{l}\text { Shares to total outputs } \\
\text { (average share, 1980s-2010s) }\end{array}$} \\
\hline & Land & $\begin{array}{l}\text { Rice } \\
\text { output }\end{array}$ & $\begin{array}{l}\text { Nonrice } \\
\text { output }\end{array}$ & $\begin{array}{l}\text { Vegetables and } \\
\text { fruits output }\end{array}$ & $\begin{array}{l}\text { Nonrice } \\
(\%)\end{array}$ & $\begin{array}{c}\text { Key nonrice } \\
\text { commodities (\%) }\end{array}$ \\
\hline Bangladesh & 1.2 & 2.8 & 3.2 & 4.2 & 36 & $\begin{array}{l}\text { Vegetables and fruits (8), } \\
\text { meat (6), milk (5) }\end{array}$ \\
\hline India & 0.6 & 1.8 & 3.1 & 3.6 & 79 & $\begin{array}{l}\text { Vegetables and fruits (21), } \\
\text { milk (17), meat (6), wheat }(6) \text {, } \\
\text { sugarcane (5) }\end{array}$ \\
\hline Nepal & 0.9 & 1.8 & 3.8 & 5.7 & 72 & $\begin{array}{l}\text { Vegetables and fruits (17), } \\
\text { meat (16), milk (12), maize } \\
\text { (5), wheat (5), potato (5) }\end{array}$ \\
\hline Pakistan & 0.4 & 1.0 & 3.1 & 2.6 & 93 & $\begin{array}{l}\text { Milk (31), meat (15), cotton } \\
\text { lint/seed (13), wheat }(10) \text {, } \\
\text { vegetables and fruits (10) }\end{array}$ \\
\hline Sri Lanka & 0.6 & 1.8 & 1.0 & 0.3 & 66 & $\begin{array}{l}\text { Vegetables and fruits ( } 17) \text {, } \\
\text { tea (12), coconuts }(9) \text {, meat } \\
\text { (7), rubber (6) }\end{array}$ \\
\hline
\end{tabular}

Source: Authors' calculations based on FAO (2020a) and USDA (2020).

TABLE 4.8 Urbanization trend in South Asian countries

\begin{tabular}{|c|c|c|c|c|c|c|c|c|c|}
\hline \multirow[b]{2}{*}{ Country } & \multicolumn{3}{|c|}{ Total population (millions) } & \multicolumn{3}{|c|}{ Urban population (millions) } & \multicolumn{3}{|c|}{ Urban population (\%) } \\
\hline & 2001 & 2011 & 2016 & 2001 & 2011 & 2016 & 2001 & 2011 & 2016 \\
\hline Afghanistan & 20.97 & 29.71 & 34.66 & 4.53 & 7.45 & 9.40 & 22 & 25 & 27 \\
\hline Bangladesh & 134.11 & 153.91 & 162.95 & 32.31 & 48.06 & 57.09 & 24 & 31 & 35 \\
\hline Bhutan & 0.59 & 0.74 & 0.80 & 0.16 & 0.26 & 0.31 & 26 & 36 & 39 \\
\hline India & $1,071.48$ & $1,247.24$ & $1,324.17$ & 299.14 & 390.09 & 438.78 & 28 & 31 & 33 \\
\hline Maldives & 0.29 & 0.38 & 0.42 & 0.08 & 0.16 & 0.19 & 29 & 41 & 47 \\
\hline Nepal & 24.16 & 27.33 & 28.98 & 3.37 & 4.69 & 5.51 & 14 & 17 & 19 \\
\hline Pakistan & 141.60 & 174.18 & 193.20 & 47.36 & 64.46 & 75.78 & 33 & 37 & 39 \\
\hline Sri Lanka & 18.80 & 20.27 & 21.20 & 3.46 & 3.71 & 3.90 & 18 & 18 & 18 \\
\hline South Asia & $1,411.99$ & $1,653.76$ & $1,766.38$ & 390.42 & 518.88 & 590.97 & 28 & 31 & 33 \\
\hline
\end{tabular}

Source: Data from World Bank (2017).

populations, especially slum dwellers, to shocks in agricultural markets (OECD-FAO 2010). Large urban settlements in SA are marked by widespread slums. The share of the urban population living in slums in SA is high (except in Bhutan and Sri Lanka), ranging from 17 percent in India to 89 percent in Afghanistan (Ellis and Roberts 2016). At least 130 million people were living 
in informal urban settlements in SA in 2009 (ADB 2014). Slum populations often do not have access to water and sanitation facilities, making them more likely to suffer from disease and malnutrition. At the same time, where it has occurred, urbanization might have been associated with the dramatic increase in the proportion of dietary energy derived from oils and fats and considerable increases in the consumption of fruits, vegetables, and dairy and other animal products. Food consumption patterns have been changing across regions, with consumption of noncereal crops growing in both rural and urban areas. Rural and urban food consumption patterns are not uniform across SA, but some common trends emerge. Food accounts for a smaller share of consumption expenditure in urban areas than in rural areas, and urban households have more diverse diets than rural households (Joshi, Parappurathu, and Kumar 2016).

\section{Nutrition Transition}

SA seems to be going through a nutrition transition (Chapter 10)—defined as the process of changes in the food environment, physical activity, and lifestyle that result in declining levels of undernutrition and increasing levels of overnutrition over time (Popkin 1993). Reduced staple crop prices in countries like India and Bangladesh, realized through investments in public research and development, have led to significant reductions in poverty, and increases in disposable incomes have led to increased dietary diversification through consumption of higher-value nonstaple commodities (Pingali 2012). Considerable progress has also been made on improving nutritional outcomes. For instance, Nepal has recorded the fastest reduction in child stunting in the world recently, from 56 percent in 2001 to 36 percent in 2016 (Nepal, Ministry of Health 2016).

Despite such transitions and progress, challenges remain. SA remains the global hub of nutrition insecurity. In 2016, two out of every five of the world's stunted children lived in SA, and more than 15 percent of children under age 5 were wasted. In fact, stunting levels in SA (38 percent) were comparable to those in SSA (37 percent) and over three times higher than in East Asia and the Pacific (12 percent) or Latin America (11 percent).

Investments into staple crops are also said to have crowded out the required investments for traditional crops that were important sources of critical nutrients, such as legumes and pulses (Pingali 2012). Consequent increases in their prices in India are considered to have reduced the consumption of these commodities (Pingali 2012). 
FIGURE 4.6 Incidence of poverty, undernourishment, stunting, and overweight in South Asia (\%)

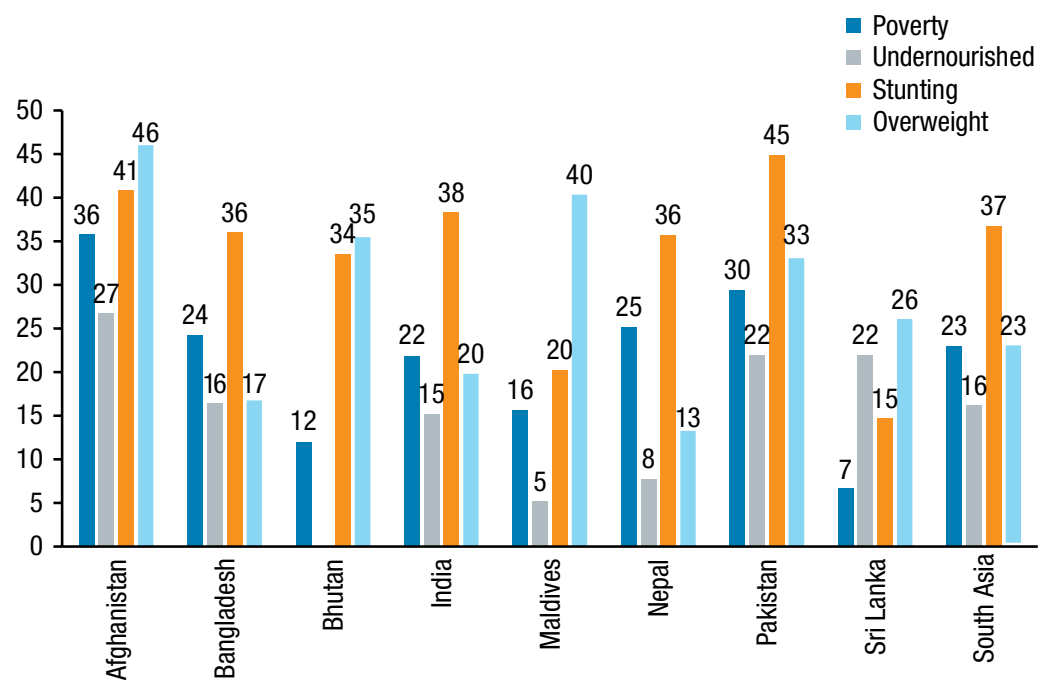

Source: Data from World Bank (2017) (poverty, undernourishment, stunting); IHME (2014) (overweight).

Note: The poverty head count data pertain to different years: Afghanistan, 2011; Bangladesh, 2016; Bhutan, 2012; India, 2011; Maldives, 2009; Nepal, 2010; Pakistan, 2013; and Sri Lanka, 2012. Undernourishment figures pertain to 2015. Stunting figures pertain to various years: Afghanistan, 2013; Bangladesh, 2014; Bhutan, 2010; India, 2015; Maldives, 2009; Nepal, 2016; Pakistan, 2012; Sri Lanka, 2012; and South Asia, 2015. Poverty head count ratio and undernourishment are given as percentage of population; stunting figures pertain to children under 5 years of age. The prevalence of overweight data are all from 2013.

South Asia has also seen a rapid emergence of overnutrition (Figure 4.6). Obesity reached 20 percent in India and 13 percent in Nepal by 2013. In India, overnutrition and associated noncommunicable diseases have also gradually spread from urban to rural areas lately (Meenakshi 2016). In SA, about one in four adults are currently overweight.

\section{Innovations and Agricultural Transformation}

This section highlights key technological and institutional innovations and key policies that might have partly enabled the agricultural growth in SA described in the previous sections. The section also discusses that these innovations have so far been associated with labor-intensive agricultural transformation in SA. Despite the gradual shift in the comparative advantages from smallholders to larger farms, such effects might not have been strong enough 
to overcome constraints for farm size expansions. Similarly, despite the growing wage gap between the agricultural sector and the nonagricultural sector, the former has remained one of the primary sources of rural employment.

\section{Technological and Institutional Innovations}

SA has seen considerable progress in technological and institutional innovations.

\section{VARIETAL TECHNOLOGIES}

For varietal technologies, public-sector-led conventional plant breeding has continued producing newer generations of improved varieties (Hossain et al. 2003). Genetic improvement efforts had been significant, not only for widely documented breeding for staple crops, but also for vegetables_-including, for example, application of molecular-based methods for breeding virus-resistant tomatoes in southern India (Weinberger and Lumpkin 2007).

Over the years in the region, the public sector has accumulated plant-breeding technologies and knowledge, as well as a supply of superior germplasms, which have raised the potential of developing hybrid varieties. At the same time, there has been increased participation of the private sector in agricultural research and development over the past few decades. Recently, hybrid varieties have been developed for maize, rice, and wheat (Matuschke, Mishra, and Qaim 2007), as well as pearl millet (Matuschke and Qaim 2008). The adoption rates of hybrid maize and hybrid rice have grown considerably. Furthermore, the increased applicability of biotechnologies (including genetic engineering) has induced private-sector participation, which has resulted in the successful development of Bt cotton and vegetable seed developments (see, for example, Krishna and Qaim 2007). Strengthening intellectual property rights is also likely to have accelerated private-sector participation (Pray and Nagarajan 2014). In countries like India, this progress has coincided with the deregulation of the seed sector that started in the 1990s (Pray and Nagarajan 2014).

\section{MECHANIZATION RELYING ON SMALL-SCALE MACHINES}

Mechanical tools have spread widely in SA over the past few decades, but possibly in ways not displacing substantial labor force in agriculture, which is appropriate in raising labor productivity in the labor-abundant environment. This has been achieved by the spread of various types of small-scale machines, including mechanical water-lifting tools, tens of millions of which are in SA (Mandal, Biggs, and Justice 2017). Since the 1990s, the use of smallscale shallow tube wells and motorized pumps has increased the extraction of 
groundwater and surface water in Bangladesh, where importation of shallow tube wells was liberalized in the 1990s (Ahmed 1995), as well as Nepal and the IGP of India (Shah et al. 2009). Power tillers have spread as well for land preparation and local transportation. At the same time, four-wheeled, riding tractors that have been more common in India and Pakistan might have been more suitable in rice-nonrice crop rotation common in parts of SA like India, and mechanization might have led to significant area expansions, sustaining the overall demand for labor (Pingali 2007). The growth of the domestic manufacturing industry, such as in India, facilitated the development of small four-wheeled tractors that are more suitable on smallholder-dominated upland in the region (Pingali 2007). These mechanization patterns may explain why the land-labor ratio did not increase with the increases in tractor HP per worker shown in Figure 4.2.

\section{INSTITUTIONAL INNOVATIONS}

SA has seen various institutional innovations in the past few decades. The growth of market institutions has been observed in the growing participation of new actors in processing, trading, and wholesale for both staple crops like rice and potato (Reardon et al. 2012) and nonstaple crops (Fafchamps, Hill, and Minten 2008). Vertical integration has also been strengthened for crops like sugarcane in India (Patlolla, Goodhue, and Sexton 2015). However, constraints remain for food sanitation along the value chain for vegetables/fruits and dairy value chains in India (Fafchamps, Hill, and Minten 2008; Kumar, Wright, and Singh 2011). Markets for minor crops have also expanded. Increased market participation has had positive effects on on-farm varietal diversity for millet in India (Takeshima and Nagarajan 2012). Marketing institutions including contract farming and cooperatives have become increasingly important for production and marketing of high-value vegetables and fruits, poultry, and higher-quality milk, which has led to the adoption of improved food safety practices (Joshi, Gulati, and Cummings 2007; Kumar et al. 2018), as will be discussed in Chapter 11 in depth.

Market institutions have also developed regionally. The South Asian Free Trade Area (SAFTA) agreement in 2004 potentially increased market integration across SA countries. Trade liberalization in the early 1990s might have improved the resilience of countries like Bangladesh against food crises caused by natural disasters like floods (del Ninno and Dorosh 2001).

Institutional innovations have also been widespread for common resource management. Transfer of forest use rights to local communities reduced forestry resource extraction in Nepal (Edmonds 2002). In India, increased 
demand for wood products has led to increased forestry cover, reversing the trend of deforestation (Foster and Rosenzweig 2003). Community irrigation systems have also grown (Bardhan 2000). Environmental efficiency has also been raised by new production technologies, such as Bt cotton that has reduced chemical pesticide use in Pakistan (Kouser and Qaim 2015).

\section{Key Policies That Partly Facilitated the Innovations}

\section{INFRASTRUCTURE DEVELOPMENT}

The increased stocks of physical infrastructure (for roads, electricity, information and communications technology, etc.) as well as institutional infrastructure have been important drivers of agricultural diversification away from traditional low-value crops to higher-value crops (Joshi, Gulati, and Cummings 2007). Better road infrastructure has often reduced the transaction costs for marketing perishable commodities like vegetables and fruits (Joshi, Gulati, and Cummings 2007). Infrastructure for veterinary institutions and artificial insemination centers for livestock was likely to have encouraged diversification in the production of livestock products (Joshi, Gulati, and Cummings 2007).

Many SA countries, including Bangladesh, India, and Pakistan, have expanded key infrastructure during the past several decades (Table 4.9). Paved roads expanded by more than five times between the 1970s and 2000s in all three countries. The number of ground line telephones multiplied by almost 5 in Bangladesh and almost 10 in India and Pakistan during the same periods. The public expenditures on infrastructure during these periods have been substantial.

\section{MACRO POLICIES ON LIBERALIZATION}

The series of innovations are also likely to have been partly induced by the economic and macro policy reforms introduced in many SA countries in the past few decades. Many SA countries, including India, Pakistan, and Sri Lanka, have gradually reduced the distortions of their exchange rates, which had typically been fixed and overvalued (Sahoo, Nataraj, and Dash 2013). India since the 1980s and Pakistan throughout the 1980s saw significant devaluations that helped raise the competitiveness of some of the export crops. Unlike some other developing countries (particularly those in SSA), these SA countries have managed to stabilize the exchange rates even after the shift to the floating exchange rate system. For example, the real exchange rate in Pakistan remained largely unchanged from the late 1980s to the 2010s (Spielman et al. 2017). 
TABLE 4.9 Improvement in infrastructure and communication in selected South Asian countries, 1970-2010

\begin{tabular}{lccc}
\hline Infrastructure/communication & Bangladesh & India & Pakistan \\
\hline Paved roads (1,000 km) & 3.7 & 334 & 19 \\
1970s & 16.4 & 1,258 & 104 \\
1990s & 21.2 & 1,818 & 167 \\
2000s & 573 & 544 & 954 \\
Percent increase between 1970s and 2000s & & & \\
\hline Landline telephones (per 1,000 people) & 1.52 & 2.51 & 3.18 \\
1970s & 2.55 & 4.03 & 4.98 \\
1980s & 2.55 & 13.06 & 14.87 \\
1990s & 6.55 & 35.91 & 27.98 \\
2000s & 470 & 1,058 & 1,044 \\
Percent increase between 1970s and 2000s & & & \\
\hline Cellular phones (per 1,000 people) & 0.3 & 0.9 & 0.7 \\
1990s & 141.4 & 154.6 & 226.8 \\
2000s & 552.0 & 674.0 & 618.0 \\
2010-2012 & & & \\
Public expenditure on infrastructure (2005 billion US\$) & 1.29 & 2.72 & 2.19 \\
1980s & 1.20 & 3.40 & 1.74 \\
1990s & 1.05 & 8.85 & 1.11 \\
2000s & & & \\
\hline
\end{tabular}

Source: Rashid et al. (2013). Reproduced by permission of the publisher; this table is not covered by the CC BY 4.0 license.

Investment policies have also been reformed in many SA countries. For example, in 1997, Pakistan allowed foreign direct investment (FDI) in the agricultural sector, though it had restricted FDI to the manufacturing sector in the previous period (Sahoo, Nataraj, and Dash 2013). Similarly, in Nepal, the share of FDI flowing into the agricultural sector started increasingly, from almost zero in 2000 to 4 percent in 2010 (Sahoo, Nataraj, and Dash 2013).

However, the extent of the effectiveness of macro policies in the agricultural sector remains uncertain. While trade liberalization policies have significantly reduced the tariff rates for nonagricultural goods, average tariffs for agricultural goods have remained higher, around 40 percent in India and 30 percent in Sri Lanka (Sahoo, Nataraj, and Dash 2013). While SA countries have seen increased shares of tax revenues originating from income tax and value-added tax, rather than seigniorage and tariff (Aizenman and Jinjarak 
2009), the taxation of agricultural incomes appears to have remained incomplete, especially in India and Pakistan.

\section{SUBSIDIES ON CREDIT, INSURANCE, AND INPUTS}

SA countries have also supported provisions of institutional credit, insurance, and agricultural inputs. For example, India has made efforts to allocate credit to the agricultural sector by increasing the overall volume of credit that goes to the sector, by waiving institutional debt for small farmers and allowing onetime settlement, and through interest-subvention schemes that reward prompt repayment by borrowers (Narayanan 2016). Consequently, in India the flow of formal-sector agricultural credit has been consistently increasing, with the ratio of agricultural credit to agricultural GDP rising from 10 percent in 1999-2000 to about 38 percent in 2012-2013 (Kumar et al. 2017), and the share of credit-financed portion out of the spending on agricultural inputs increasing from 21 percent in 1995/1996-2003/2004 to 69 percent in 2004/2005-2011/2012 (Narayanan 2016). Institutional credit has been positively associated with agricultural development in various ways in countries like India (see, for example, Narayanan 2016). Between the mid-1990s and early 2010s, greater credit flows had been associated with the increased use of chemical fertilizer, use of pesticides, or investments into agricultural capital like tractors. At the same time, the effects of credit on agricultural GDP, efficiency, and productivity have been relatively limited (Narayanan 2016). These patterns suggest that institutional credit might have been more associated with the increase in agricultural productivity where capital inputs (purchased by credit) offered higher productivity than noncapital inputs (see Chapter 16 for further discussion).

In Bangladesh, formal credit for machinery purchase has been increasingly provided by the importers that have comparative advantages in monitoring and loan payment collections, rather than directly through the bank. Khandker (2007) found that microfinance institutions in Bangladesh enhanced flood-affected households' access to finance and thereby played a central role in enhancing their coping ability after devastating floods.

The uptake of agricultural insurance has been rising, albeit slowly, in India. By 2016, 57 million farmers in India had been covered by some type of insurance (Gulati, Terway, and Hussain 2018). The cost-effectiveness of these subsidized insurance programs remains ambiguous with limited empirical evidence (see Chapter 17). In parts of India, indexed insurance increased investments into potentially higher-return cash crops that are more sensitive to rainfall (Cole et al. 2013). In parts of Bangladesh, indexed insurance significantly 
enhanced risk-management effects and expanded cultivated area and spending on agricultural inputs (Hill et al. 2019). However, further studies are needed on the effects of agricultural insurance on agricultural productivity, profitability, and farm incomes, for which evidence remains thin.

Among input subsidies, fertilizer subsidies often accounted for 2-3 percent of total public expenditures and often more than 30 percent of agricultural expenditures in Bangladesh, India, and Pakistan between 1980 and 2010 (Rashid et al. 2013). These fertilizer subsidies were effective in reducing fertilizer prices during this period—as much as 30 percent in India, 9 percent in Bangladesh, and 3 percent in Pakistan (Rashid et al. 2013). However, it is also important to note that these subsidies also led to significant distortions of fertilizer markets. Combined with exchange rate distortion, fertilizer prices often deviated substantially from international prices (Rashid et al. 2013). The subsidies have also been rather regressive; that is, larger farms generally benefited more than smallholders. Furthermore, fertilizer subsidies have also been considered partly responsible for various environmental damages caused by their overuse, including groundwater pollution in Bangladesh (Alauddin and Quiggin 2008) and India (Rashid et al. 2013), as well as air pollution in India (Aneja et al. 2012).

\section{Farm Size and Production Efficiency}

The average farm size in SA has been declining over the past several decades. This trend has been consistent across many SA countries, including Bangladesh and Nepal with very small farm sizes (less than 1 hectare on average), India with slightly larger farm sizes (around 1 hectare on average), and Pakistan with modestly larger farm sizes (around 3 hectares on average) (Table 4.10).

Declining farm sizes and the process of land fragmentation in SA countries have been partly influenced by government policies in these countries, including the law of inheritance of paternal property, lack of progressive tax on inherited land, heterogeneous land quality, and an underdeveloped land market (Niroula and Thapa 2005). Pakistan has imposed a progressive land tax, where larger farms are taxed at a higher rate than smaller farms (Adamopoulos and Restuccia 2014). In India and Nepal, a land reform program called the land-to-the-tiller program was implemented, albeit with a limited implementation capacity, whereby the land was transferred from large landholders to tenants who actually cultivate the land, and ceilings were set for the land ownership. 
TABLE 4.10 Declining farm sizes in selected South Asian countries

\begin{tabular}{lcc}
\hline Country & Year & Average holding size (ha) \\
\hline Bangladesh & 1983 & 0.80 \\
& 1996 & 0.47 \\
& 2008 & 0.37 \\
\hline India & 1971 & 2.28 \\
& 1986 & 1.69 \\
& 1991 & 1.57 \\
& $1995-1996$ & 1.41 \\
& 2001 & 1.33 \\
& $2005-2006$ & 1.23 \\
Nepal & $2010-2011$ & 1.15 \\
\hline Pakistan & 1980 & 1.12 \\
& 1990 & 0.95 \\
& 2000 & 0.79 \\
& 2011 & 0.66 \\
\hline Sri Lanka & 1970 & 5.29 \\
& 1980 & 4.70 \\
& 1990 & 3.78 \\
& 2000 & 3.08 \\
& 2010 & 2.59 \\
& 1960 & 1.61 \\
& 1970 & 1.24 \\
& 1980 & 1.08 \\
& 2002 & 0.47 \\
\hline
\end{tabular}

Source: Data from FAO (2020c).

Evidence suggests potentially negative effects of declining farm size, as well as fragmentation, on productivity and efficiency. Adamopoulos and Restuccia (2014) estimated that the aforementioned tax policies in Pakistan reduced average farm size and agricultural productivity by 3 percent. The aforementioned policies on the land-to-the-tiller program in India and Nepal discouraged optimal land concentration that would achieve economies of scale in production (Otsuka, Liu, and Yamauchi 2016).

The negative productivity and efficiency effects of declining farm size have also been aggravated by accelerating land fragmentation. Land fragmentation was found to increase the cost of cultivation in India (Deininger 2017) 
and had negative effects on rice productivity and efficiency in Bangladesh (Rahman and Rahman 2009). Niroula and Thapa (2005) conclude, based on reviews of the literature in SA, that fragmentation of small landholdings and tiny land parcels have been detrimental to land conservation and economic gain and that they have discouraged farmers' adoption of agricultural innovations.

Meanwhile, relations between farm size and productivity have been changed by growing adoptions of mechanization in SA in the last few decades. Even though the machine rental markets providing hiring services have been relatively efficient and have managed to enable not only larger farmers but also smallholders to adopt mechanization, mechanization, particularly recent large-scale mechanization, has shifted the comparative advantage to larger farms. In Nepal, the adoptions of mechanical technologies (tractors, in particular) have directly raised the returns to scale in agriculture, shifting the comparative advantage from smallholders to larger farms (Takeshima 2017a). Aside from mechanization, Deininger et al. (2018) argue, the labor market imperfections in India have dissipated over time, and this too has weakened the inverse relationship between farm size and output per area. According to them, previously family labor was overused for farming because they were rationed out of off-farm labor markets, which were less functioning, and the extent of overuse was greater among smaller farms with greater family labor endowments. In the last few decades, however, an increasingly functioning labor market has started absorbing more family labor into the off-farm market, while reducing on-farm family labor use to a more optimal level.

With labor market transformation, increased infusion of capital into the agricultural sector in the form of mechanization, and the resulting shift in comparative advantages toward larger farms, the institutional failures in developing efficient land markets are now becoming increasingly important bottlenecks in SA.

\section{Emerging Rural Employment Opportunities}

In SA, the agricultural sector has remained the major source of rural employment in the past few decades, despite the gradual expansion of the nonfarm sector. The persistently high contribution of the agricultural sector as the source of rural employment is consistent with the presentations in earlier sections, where labor use per hectare has remained unchanged, even though labor productivity in agriculture has risen substantially in many SA countries. In India, the agricultural sector has long competed with the industrial and service sectors for workers. Where labor mobility has been low, the industrial 
sector has often moved to areas with lower agricultural productivity and thus lower wages (Foster and Rosenzweig 2004). However, rural labor mobility was not always low. In Nepal and Pakistan, the adoption of modern varieties in favorable areas benefited marginal areas through increased labor demand and migration (Upadhyaya, Otsuka, and David 1990; Renkow 1993).

Rural employment in the agricultural sector has remained high and, in some cases, has increased in absolute terms. The crop sector rather than the livestock sector has often been the major source of agricultural employment, as in, for example, Pakistan (Spielman et al. 2017). New agricultural technologies in SA, particularly in India, have been relatively more skill intensive, raising the returns to primary schooling (Foster and Rosenzweig 1996) and thereby raising the demand for moderately educated labor. Output growth has increased demand for harvesting labor, even for labor-saving varieties like $\mathrm{Bt}$ cotton in India (Subramanian and Qaim 2009). Such growth for harvesting labor is, however, also a reflection of the fact that wages are still low, preventing the spread of mechanical harvesters that has been widely observed in East Asia lately. Once the wage level rises to the critical threshold, rural employment in SA is likely to shift considerably to the nonfarm sector.

\section{NONFARM SECTOR}

In SA, the share of rural employment in the nonfarm sector has remained low and has just started rising gradually. Table 4.11 compares the shares of rural employment among different economic activities in the five SA countries in recent decades. Direct comparisons across countries or over time should be made with caution, due to the differences in the classifications of activities, measurements, and periods. However, these figures collectively provide useful insights.

The construction sector has been one of the fastest-growing sources of rural employment among the nonfarm sector, particularly in India and Nepal. To a lesser extent, rural employment in the manufacturing of farm products has grown in parallel with the overall farm output growth. The rice-milling sector, which is still dominated by small-scale mills in India and Bangladesh, and potato cold storage facilities in Bangladesh have provided significant sources of employment despite relatively high capital intensity (Reardon et al. 2012). ${ }^{4}$

4 For example, in Bangladesh, despite the rising rice yield and productivity, traditional small-scale mills still provide the majority of milled rice (Reardon et al. 2012). 
TABLE 4.11 Shares of rural employment in selected South Asian countries, by activities (\%)

\begin{tabular}{|c|c|c|c|c|c|c|c|}
\hline Country & Period & Agriculture & Construction & Transport & Manufacture & $\begin{array}{l}\text { Trade } \\
\text { etc. }\end{array}$ & $\begin{array}{c}\text { Other } \\
\text { services }\end{array}$ \\
\hline Bangladesh $^{\mathrm{a}}$ & 2000 & 58 & 3 & 17 & 10 & - & 12 \\
\hline \multirow[t]{2}{*}{ India ${ }^{b}$} & $\begin{array}{l}2004- \\
2005\end{array}$ & 73 & 5 & 3 & 8 & 6 & 5 \\
\hline & $\begin{array}{l}2009- \\
2010\end{array}$ & 68 & 10 & 3 & 7 & 6 & 6 \\
\hline \multirow[t]{2}{*}{ Nepalc } & 1995 & 83 & 1 & 1 & 2 & 0 & 13 \\
\hline & 2010 & 61 & 7 & 2 & 4 & 1 & 25 \\
\hline \multirow[t]{2}{*}{ Pakistan $^{d}$} & $\begin{array}{l}2005 / \\
2006\end{array}$ & 43 & - & - & - & \multicolumn{2}{|c|}{$\begin{array}{l}\text { Industry: 21, } \\
\text { Services: } 36\end{array}$} \\
\hline & $\begin{array}{l}2013 / \\
2014\end{array}$ & 44 & - & - & - & \multicolumn{2}{|c|}{$\begin{array}{l}\text { Industry: 23, } \\
\text { Services: } 34\end{array}$} \\
\hline Sri Lanka & 2003 & 33 & - & - & 27 & 25 & 14 \\
\hline
\end{tabular}

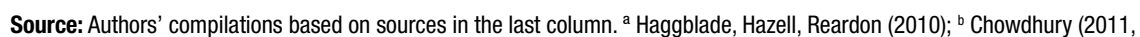

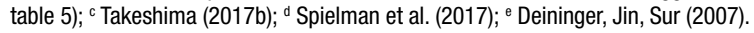

Note: For Bangladesh, "transport" includes "commerce"; "other services" includes "personal, financial, and community services"; "construction" includes "construction and utilities mining." Transport includes "transport and commerce."

For India, "construction" includes "mining"; "trade" includes "trade, hotel, and restaurant." "Other services" includes "electricity, gas, and water supply; finance; real estate, etc.; and public administration and other services."

For Nepal, figures for the urban and rural sectors, as well as male and female, and across agroecological belts in Takeshima (2017b) are combined using the population weights. Figures are also based on the share of hours engaged in each activity.

For Pakistan, figures for 2005/2006 and 2013/2014 include urban sector, which account for about one-third of the country's population.

For Sri Lanka, agriculture data is from ADB (2007). Manufacture, trade, and other services includes nonfarm "enterprises" and not wage employment. Figures are based on Deininger, Jin, Sur (2007), multiplied by the share of nonfarm economic activities to total rural employment.

- = data not available.

Employment growth in the manufacturing of nonfarm products has been driven by textile industries. For example, the garment industry has grown considerably in Bangladesh, and by 2007-2008, 2.5 million workers had been employed in the sector (Mottaleb and Sonobe 2011). The growth of the Bangladesh garment industry has been enabled primarily by international transfer of production technologies and skills in management and international marketing, coupled with enhanced education levels (Mottaleb and Sonobe 2011). Furthermore, Bangladesh succeeded in creating an enabling environment for garment-sector growth by maintaining stability and predictability of garment-industry policies, rather than focusing on heavier interventions that may be more substantial in scope but can also bring significant unpredictability from the private sector's perspectives (Ahmed, Greenleaf, 
and Sacks 2014). Where these conditions exist, export-oriented manufacturing may grow substantially even in the rural areas in SA (see Chapter 11).

Other major sources of rural employment include government services. In the 1990s, government jobs provided about 25 percent of rural nonfarm earnings in rural Pakistan and nearly 20 percent of rural nonfarm employment in rural India (Haggblade, Hazell, and Reardon 2010).

The expansion of public works social protection policies has had certain effects as well on rural employment in SA. A notable example is India's Rural Employment Guarantee program, which has offered employment on local public works to any rural adult residents demanding work for up to 100 days. This program has been one of the largest public works schemes and had covered about 30 percent of rural households in India from 2009 to 2015, generating more than 2 billion person-days of work per year from 2008 to 2014 (Drèze and Khera 2017). Although there are still issues with these programs, including corruption and the lack of accountability in program implementation, the program has been found to significantly reduce lean-season poverty, to increase consumption particularly among scheduled castes (Bose 2017; Drèze and Khera 2017), and to increase wages (Merfeld 2019).

\section{Potential Factors Limiting Structural Transformation in South Asia}

Despite the agricultural and rural development described in SA in this chapter, the region has still lagged behind Northeast Asia (such as the Republic of Korea) and some countries in Southeast Asia in terms of structural transformation. This is despite the fact that these countries had started with similar factor endowments and level of economic development in the 1950s and had similar access to the Green Revolution technologies. While it is difficult to pinpoint exact factors that have led to such divergence, two potential factors are irrigation and education.

The difference in the use of irrigation for Green Revolution technologies between SA and East Asia might have been responsible for the differences in productivity growth between these regions. In Bangladesh and India, which account for the majority of the rice area in SA, the share of the total rice area that was irrigated remained lower than in many East Asian countries, and this has been consistent with differential rice yields in these regions (Figure 4.7). Often, irrigation had been the most important factor affecting the adoption of improved rice varieties in Asia during the Green Revolution (Estudillo and Otsuka 2012). This was because Green Revolution technologies had been developed more for irrigated areas, while the development of varieties for 
FIGURE 4.7 Share of rice area irrigated (\%) and rice yield (tons per hectare) in selected Asian countries and regions

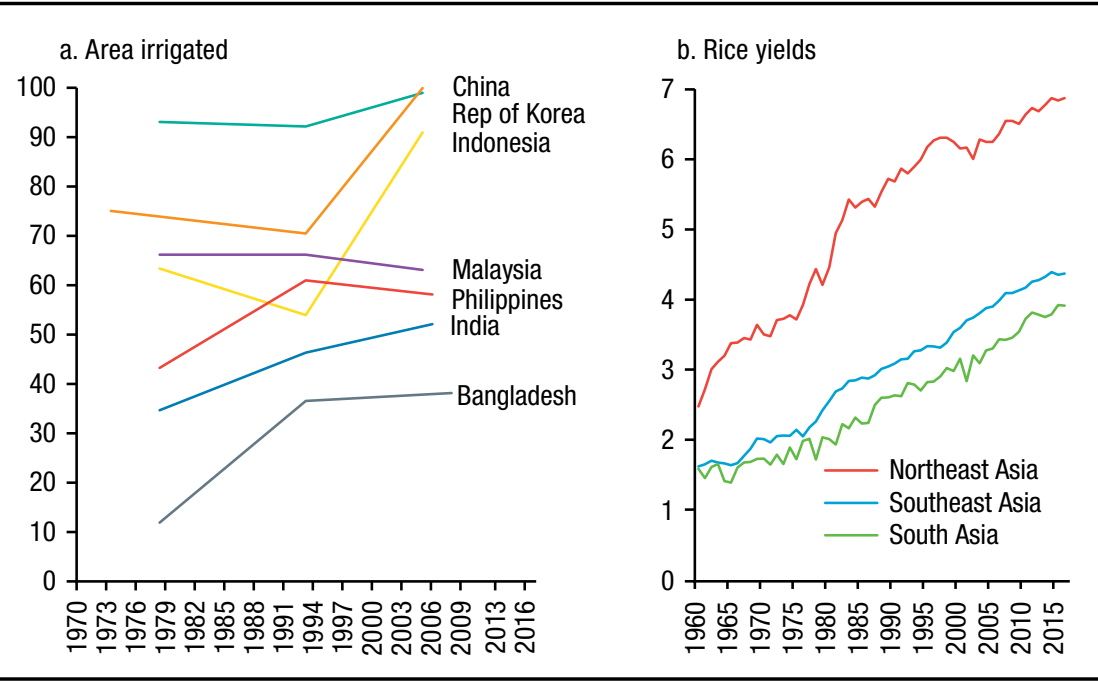

Source: FA0 (2020b) for post-2000 shares of irrigated areas; FA0 (2020a) for rice yield; Pingali and Hussain (1998) for shares of irrigated areas for 1978 and 1992-1994.

rainfed areas came much later. Importantly, however, SA countries have also been catching up with East Asia. In the first 30 years of the country's independence, Bangladesh invested US $\$ 5$ billion (in real terms) in large-scale irrigation projects, in part through the financial loans from the development partner (Rashid et al. 2013). Similarly, India invested more than $\$ 9$ billion in public irrigation projects between 1971 and 1995 (Rashid et al. 2013). These investments may help narrow the transformation gap between SA and East Asia.

Slower labor movement out of the agricultural sector in SA might have been partly associated with a historically lower human capital level in the region. Average education levels among adults have remained lower than those in East Asia over the last half century, despite the gradual increases during this period (Figure 4.8). These differences are likely to have affected the overall economic growth in these regions. Siddiqui and Rehman (2017) suggest that educational differences largely affected the growth difference between East Asia and SA. In India and China, education has had similar effects on growth, and thus the gap in education between these two countries has accounted for the gap in economic transformation (Bosworth and Collins 2008). 
FIGURE 4.8 Average years of education among adults (15 years old and older) in selected South Asian countries contrasted with East Asian countries

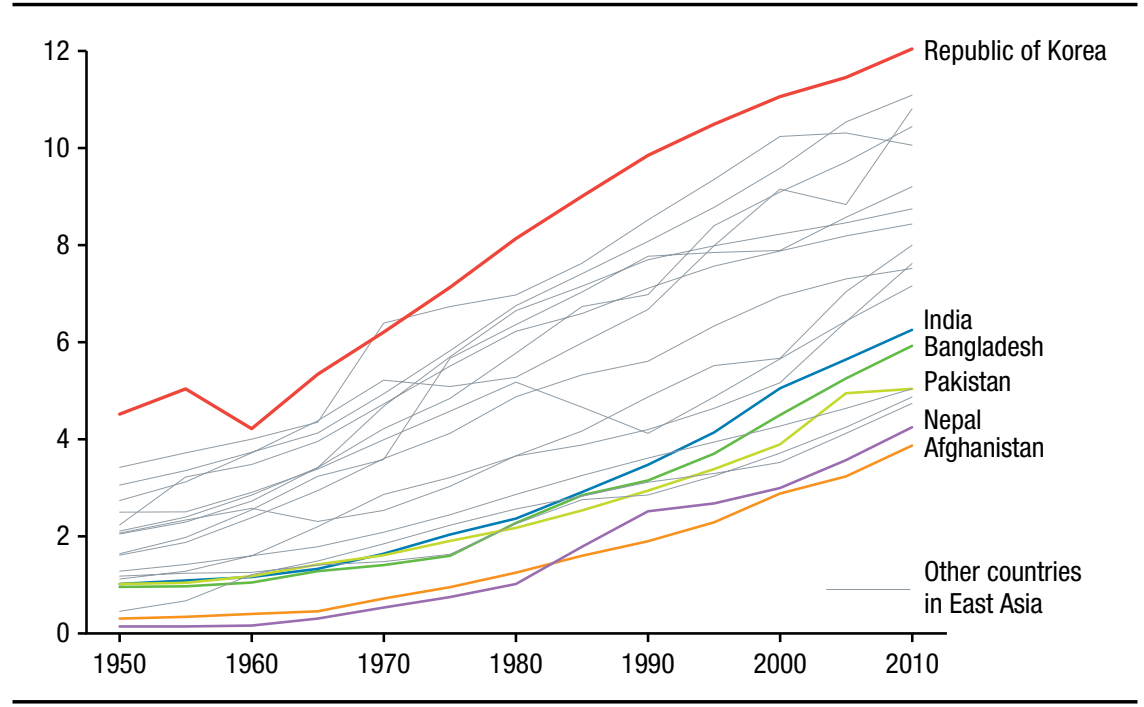

Source: Authors' calculations based on Barro and Lee (2013).

\section{Concluding Remarks}

SA has one of the highest labor-land ratios in the world. However, the region seems to have followed the Asian-type agricultural growth path characterized by Hayami and Ruttan (1985). Since the 1980s, even the most land-scarce countries, like Bangladesh and Nepal, seem to have started reversing the previous trend of declining labor productivity up to the 1970s. The region appears to be finally shifting toward the beginning of the transformation process with greater increases in labor productivity than land productivity, which many advanced countries have experienced in the past. The underlying technology landscape seems to have shifted as well; mechanization growth in the past three decades has been considerable and seems to have reached the stage where further increases in power and machinery use are associated with a significant increase in the land-labor ratio. This is consistent with the growing evidence in the region that smaller farms are becoming inefficient relative to the larger farms. Institutional failures in developing land markets can become increasingly important bottlenecks.

Land productivity growth in SA has followed diverse patterns, with some countries shifting from cereals to higher-value vegetables and fruits, some 
countries shifting from traditional export crops to cereals, and some countries shifting from traditional cereals to higher-value cereals. Yet, there has been a convergence of agricultural output per unit of land within SA.

Technological innovations, ranging from the adoption of machines and chemicals to improved varieties, have been led by both the public and the private sector in SA. Public support and institutional innovations seem to be associated with expanded provisions of agricultural finance and insurance, as well as collective actions in milk production, improved food safety practices, and management of common resources including irrigation facilities and forests. Liberalization and regional integration might have facilitated the trade growths of agricultural commodities within the region, and they have potentially improved national resilience against food crises.

SA, however, still faces various emerging challenges. Natural resources, including water resources, continue to degrade. Nutritional improvements still seem to lag behind agricultural growth. The varying agricultural growth might also have important implications for inequality, between urban or peri-urban areas experiencing fast modernization and rural areas where the low-paying agricultural sector remains the dominant source of employment. Raising the labor productivity in agriculture is likely to be critical in SA, and it will require, among other things, careful balancing of support for rural nonfarm employment, facilitating labor movement from farm to the nonfarm sector, and continued support for the farm sector in ways that lead to productivity enhancement without resource degradation.

\section{References}

Adamopoulos, T., and D. Restuccia. 2014. “The Size Distribution of Farms and International Productivity Differences." American Economic Review 104 (6): 1667-1697.

ADB (Asian Development Bank). 2007. Sri Lanka Country Assistance Program Evaluation: Agriculture and Natural Resources Sector Assistance Evaluation. Supplementary Appendix A. Operations Evaluation Department, ADB.

- 2014. Urban Poverty in Asia. Mandaluyong, Philippines.

Ahmed, F., A. Greenleaf, and A. Sacks. 2014. "The Paradox of Export Growth in Areas of Weak Governance: The Case of the Ready Made Garment Sector in Bangladesh.” World Development 56: 258-271.

Ahmed, R. 1995. "Liberalization of Agricultural Input Markets in Bangladesh: Process, Impact, and Lessons." Agricultural Economics 12 (2): 115-128. 
Aizenman, J., and Y. Jinjarak. 2009. “Globalisation and Developing Countries: A Shrinking Tax Base?" Journal of Development Studies 45 (5): 653-671.

Alauddin, M., and J. Quiggin. 2008. “Agricultural Intensification, Irrigation and the Environment in South Asia: Issues and Policy Options." Ecological Economics 65 (1): 111-124.

Aneja, V. P., W. H. Schlesinger, J. W. Erisman, S. N. Behera, M. Sharma, and W. Battye. 2012. "Reactive Nitrogen Emissions from Crop and Livestock Farming in India." Atmospheric Environment 47: 92-103.

Bardhan, P. 2000. "Irrigation and Cooperation: An Empirical Analysis of 48 Irrigation Communities in South India." Economic Development and Cultural Change 48 (4): 847-865.

Barro, R, and J. W. Lee. 2013. "A New Data Set of Educational Attainment in the World, 19502010." Journal of Development Economics 104: 184-198.

Bose, N. 2017. "Raising Consumption through India's National Rural Employment Guarantee Scheme." World Development 96: 245-263.

Bosworth, B., and S. M. Collins. 2008. "Accounting for Growth: Comparing China and India." Journal of Economic Perspectives 22 (1): 45-66.

Chowdhury, S. 2011. "Employment in India: What Does the Latest Data Show?" Economic and Political Weekly 46 (32): 23-26.

Coelli, T., and D. Rao. 2005. "Total Factor Productivity Growth in Agriculture: A Malmquist Index Analysis of 93 Countries, 1980-2000." Agricultural Economics 32 (S1): 115-134.

Cole, S., X. Gine, J. Tobacman, P. Topalova, R. Townsend, and J. Vickery. 2013. “Barriers to Household Risk Management: Evidence from India." American Economic Journal: Applied Economics 5 (1): 104-135.

Deininger, K., S. Jin, Y. Liu, and S. K. Singh. 2018. "Can Labor Market Imperfections Explain Changes in the Inverse Farm Size-Productivity Relationship? Longitudinal Evidence from Rural India." Land Economics 94 (2): 239-258.

Deininger, K., S. Jin, and M. Sur. 2007. “Sri Lanka’s Rural Non-Farm Economy: Removing Constraints to Pro-Poor Growth." World Development 35 (12): 2056-2078.

Deininger, K., D. Monchuk, H. Nagarajan, and S. Singh. 2017. "Does Land Fragmentation Increase the Cost of Cultivation? Evidence from India." Journal of Development Studies 53 (1): 82-98.

del Ninno, C., and P. A. Dorosh. 2001. "Averting a Food Crisis: Private Imports and Public Targeted Distribution in Bangladesh after the 1998 Flood." Agricultural Economics 25 (2-3): $337-346$.

Drèze, J., and R. Khera. 2017. "Recent Social Security Initiatives in India." World Development 98: 555-572. 
Edmonds, E. 2002. "Government-Initiated Community Resource Management and Local Resource Extraction from Nepal's Forests." Journal of Development Economics 68 (1): 89-115.

Ellis, P., and M. Roberts. 2016. Leveraging Urbanization in South Asia: Managing Spatial Transformation for Prosperity and Livability. Washington, DC: World Bank.

Estudillo, J. P., and K. Otsuka. 2012. “Lessons from the Asian Green Revolution in Rice.” In $A n$ African Green Revolution: Finding Ways to Boost Productivity on Small Farms, edited by K. Otsuka and D. Larson, Chapter 2. Switzerland: Springer.

Fafchamps, M., R. V. Hill, and B. Minten. 2008. "Quality Control in Nonstaple Food Markets: Evidence from India.” Agricultural Economics 38 (3): 251-266.

FAO (Food and Agriculture Organization of the United Nations). 1994. Land Degradation in South Asia: Its Severity, Causes and Effects on People. World Soil Resources Report 789. Rome.

_. 2019. "Fishery and Aquaculture Statistics. Global Aquaculture Production 1950-2017 (FishstatJ).” FishStatJ—Software for Fishery and Aquaculture Statistical Time Series. www .fao.org/fishery/statistics/software/fishstatj/en.

_.2020a. FAOSTAT database. Accessed 2020. http://www.fao.org/faostat/en/\#data.

- 2020b. AQUASTAT: FAO’s Global Information System on Water and Agriculture. Accessed June 8, 2020. http://www.fao.org/aquastat/en/databases/.

_.2020c. "World Programme for the Census of Agriculture." Accessed June 8, 2020. http:// www.fao.org/world-census-agriculture/en/.

Foster, A., and M. Rosenzweig. 1996. "Technical Change and Human Capital Returns and Investments: Evidence from the Green Revolution.” American Economic Review 86 (4): 931-953.

- 2003. "Economic Growth and the Rise of Forests." Quarterly Journal of Economics 118 (2): 601-637.

- 2004. "Agricultural Productivity Growth, Rural Economic Diversity, and Economic Reform: India, 1970-2000.” Economic Development and Cultural Change 52 (3): 509-542.

Gulati, A., P. Terway, and S. Hussain. 2018. Crop Insurance in India: Key Issues and Way Forward. Working Paper 352. Indian Council for Research on International Economic Relations. New Delhi.

Gupta, S., B. Minten, N. Rao, and T. Reardon. 2017. “The Rapid Diffusion of Herbicides in Farming in India: Patterns, Determinants, and Effects on Labor Productivity." European Journal of Development Research 29 (3): 596-613.

Haggblade, S., P. Hazell, and T. Reardon. 2010. “The Rural Non-Farm Economy: Prospects for Growth and Poverty Reduction.” World Development 38 (10): 1429-1441. 
Hayami, Y., and V. W. Ruttan. 1985. Agricultural Development: An International Perspective. Baltimore: Johns Hopkins University Press.

Hill, R., N. Kumar, N. Magnan, S. Makhija, F. de Nicola, D. Spielman, and P. Ward. 2019. “Ex Ante and Ex Post Effects of Hybrid Index Insurance in Bangladesh." Journal of Development Economics 136: 1-17.

Hossain, M., D. Gollin, V. Camanilla et al. 2003. "International Research and Genetic Improvement in Rice: Evidence from Asia and Latin America." In Crop Variety Improvement and Its Effect on Productivity: The Impact of International Agricultural Research, edited by R. Evenson and D. Gollin. Wallingford, UK: CABI.

IMHE (Institute for Health Metrics and Evaluation). 2014. Global Burden of Disease Study 2013. Seattle.

Joshi, P. K., A. Gulati, and R. Cummings. 2007. Agricultural Diversification and Smallholders in South Asia. Chicago: Academic Foundation.

Joshi, P. K., S. Parappurathu, and P. Kumar. 2016. "Dynamics of Food Consumption and Nutrient Insecurity in India." Proceedings of Indian National Science Academy 82 (5): 1587-1599.

Kawarazuka, N., and C. Béné. 2010. "Linking Small-Scale Fisheries and Aquaculture to Household Nutritional Security: An Overview." Food Security 2 (4): 343-357.

Khandker, S. 2007. “Coping with Flood: Role of Institutions in Bangladesh." Agricultural Economics 36 (2): 169-180.

Kouser, S., and M. Qaim. 2015. "Bt Cotton, Pesticide Use and Environmental Efficiency in Pakistan." Journal of Agricultural Economics 66 (1): 66-86.

Krishna, V., and M. Qaim. 2007. "Estimating the Adoption of Bt Eggplant in India: Who Benefits from Public-Private Partnership?" Food Policy 32 (5): 523-543.

Kumar, A., A. K. Mishra, S. Saroj, and P. K. Joshi. 2017. "Institutional vs Non-Institutional Credit to Agricultural Households in India: Evidence on Impact from a National Farmers' Survey." Economic Systems 41: 420-432.

Kumar, A., S. Saroj, P. K. Joshi, and H. Takeshima. 2018. “Does Cooperative Membership Improve Household Welfare? Evidence from a Panel Data Analysis of Smallholder Dairy Farmers in Bihar, India." Food Policy 75: 24-36.

Kumar, A., I. Wright, and D. Singh. 2011. “Adoption of Food Safety Practices in Milk Production: Implications for Dairy Farmers in India." Journal of International Food \& Argibusiness Marketing 23 (4): 330-344.

Kumar, P., A. Kumar, and S. Mittal. 2004. “Total Factor Productivity of Crop Sector in the Indo-Gangetic Plain of India: Sustainability Issues Revisited." Indian Economic Review 39 (1): 169-201. 
Mandal, S., S. Biggs, and S. Justice. 2017. Rural Mechanization: A Driver in Agricultural Change and Rural Development. Dhaka: Institute for Inclusive Finance and Development.

Matuschke, I., R. Mishra, and M. Qaim. 2007. "Adoption and Impact of Hybrid Wheat in India.” World Development 35 (8): 1422-1435.

Matuschke, I., and M. Qaim. 2008. “Seed Market Privatisation and Farmers' Access to Crop Technologies: The Case of Hybrid Pearl Millet Adoption in India." Journal of Agricultural Economics 59 (3): 498-515.

McDermott, J., S. Staal, H. Freeman, M. Herrero, and J. Van de Steeg. 2010. “Sustaining Intensification of Smallholder Livestock Systems in the Tropics." Livestock Science 130 (1): 95-109.

Meenakshi, J. V. 2016. "Trends and Patterns in the Triple Burden of Malnutrition in India." Agricultural Economics 47 (S1): 115-134.

Merfeld, J. D. 2019. "Spatially Heterogeneous Effects of a Public Works Program." Journal of Development Economics 136: 151-167.

Minten, B., K. A. S. Murshid, and T. Reardon. 2013. "Food Quality Changes and Implications: Evidence from the Rice Value Chain of Bangladesh.” World Development 42: 100-113.

Minten, B., K. M. Singh, and R. Sutradhar. 2013. "Branding and Agricultural Value Chains in Developing Countries: Insights from Bihar (India).” Food Policy 38: 23-34.

Mottaleb, K., and T. Sonobe. 2011. "An Inquiry into the Rapid Growth of the Garment Industry in Bangladesh." Economic Development and Cultural Change 60 (1): 67-89.

Mukherjee, A., and Y. Kuroda. 2003. "Productivity Growth in Indian Agriculture: Is There Evidence of Convergence across States?” Agricultural Economics 29 (1): 43-53.

Murgai, R. 2001. "The Green Revolution and the Productivity Paradox: Evidence from the Indian Punjab." Agricultural Economics 25 (2-3): 199-209.

Narayanan, S. 2016. "The Productivity of Agricultural Credit in India." Agricultural Economics 47 (4): 399-409.

Nepal Ministry of Health. 2016. Nepal Demographic and Health Survey 2016. Kathmandu, Nepal: $\mathrm{MOH} / \mathrm{Nepal,} \mathrm{New} \mathrm{ERA/Nepal,} \mathrm{and} \mathrm{ICF.}$

Nin-Pratt, A., and B. Yu. 2010. "Getting Implicit Shadow Prices Right for the Estimation of the Malmquist Index: The Case of Agricultural Total Factor Productivity in Developing Countries." Agricultural Economics 41 (3-4): 349-360.

Niroula, G., and G. Thapa. 2005. "Impacts and Causes of Land Fragmentation, and Lessons Learned from Land Consolidation in South Asia." Land Use Policy 22 (4): 358-372.

OECD-FAO (Organisation for Economic Co-operation and Development-Food and Agriculture Organization of the United Nations). 2010. OECD-FAO Agricultural Outlook 2010. Paris. 
Otsuka, K., Y. Liu, and F. Yamauchi. 2016. "Growing Advantage of Large Farms in Asia and Its Implications for Global Food Security." Global Food Security 11: 5-10.

Patlolla, S., R. Goodhue, and R. Sexton. 2015. “Managing Quantity, Quality, and Timing in Indian Cane Sugar Production: Ex Post Marketing Permits or Ex Ante Production Contracts?” World Bank Economic Review 29 (3): 606-630.

Paul, B., and C. Vogl. 2011. "Impacts of Shrimp Farming in Bangladesh: Challenges and Alternatives." Ocean \& Coastal Management 54 (3): 201-211.

Pingali, P., and M. Hossain, eds. 1998. Impact of Rice Research. Los Baños, Philippines: Thailand Development Research Institute and International Rice Research Institute.

- 2007. "Agricultural Mechanization: Adoption Patterns and Economic Impact." In Handbook of Agricultural Economics, edited by R. Evenson and P. Pingali, 2779-2805. Amsterdam: Elsevier.

- 2012. "Green Revolution: Impacts, Limits, and the Path Ahead." Proceedings of the National Academy of Sciences 109 (31): 12302-12308.

Popkin, B. 1993. "Nutritional Patterns and Transitions." Population and Development Review 19

(1): $138-157$.

Pray, C., and L. Nagarajan. 2014. "The Transformation of the Indian Agricultural Input Industry: Has It Increased Agricultural R\&D?” Agricultural Economics 45 (S1): 145-156.

Rada, N. 2016. “India's Post-Green-Revolution Agricultural Performance: What Is Driving Growth?” Agricultural Economics 47 (3): 341-350.

Rahman, S., and M. Rahman. 2009. "Impact of Land Fragmentation and Resource Ownership on Productivity and Efficiency: The Case of Rice Producers in Bangladesh." Land Use Policy 26 (1): 9-103.

Rahman, S., and R. Salim. 2013. "Six Decades of Total Factor Productivity Change and Sources of Growth in Bangladesh Agriculture (1948-2008)." Journal of Agricultural Economics 64 (2): 275-294.

Rashid, S., P. Dorosh, M. Malek, and S. Lenma. 2013. "Modern Input Promotion in SubSaharan Africa: Insights from Asian Green Revolution.” Agricultural Economics 44 (6): $705-721$.

Reardon, T., K. Chen, B. Minten, and L. Adriano. 2012. The Quiet Revolution in Staple Food Value Chains in Asia: Enter the Dragon, the Elephant, and the Tiger. Washington, DC: Asian Development Bank and International Food Policy Research Institute.

Renkow, M. 1993. "Differential Technology Adoption and Income Distribution in Pakistan: Implications for Research Resource Allocation." American Journal of Agricultural Economics 75: 33-43. 
Sahoo, P., G. Nataraj, and R. Dash. 2013. Foreign Direct Investment in South Asia: Policy, Impact, Determinants and Challenges. Switzerland: Springer Science \& Business Media.

Shah, T., M. Hassan, M. Khattak, P. Banerjee, O. Singh, and S. Rehman. 2009. "Is Irrigation Water Free? A Reality Check in the Indo-Gangetic Basin." World Development 37 (2): 422-434.

Siddiqui, A., and A. Rehman. 2017. "The Human Capital and Economic Growth Nexus: In East and South Asia." Applied Economics 49 (28): 2697-2710.

Spielman, D., S. Malik, P. Dorosh, and N. Ahmad. 2017. Agriculture and the Rural Economy in Pakistan: Issues, Outlooks, and Policy Priorities. Philadelphia: University of Pennsylvania Press.

Subramanian, A., and M. Qaim. 2009. "Village-Wide Effects of Agricultural Biotechnology: The Case of Bt Cotton in India." World Development 37 (1): 256-267.

Suhariyanto, K., and C. Thirtle. 2001. “Asian Agricultural Productivity and Convergence." Journal of Agricultural Economics 52 (3): 96-110.

Takeshima, H. 2017a. "Custom-Hired Tractor Services and Returns to Scale in Smallholder Agriculture: A Production Function Approach.” Agricultural Economics 48 (3): 363-372.

- 2017b. "Overview of the Evolution of Agricultural Mechanization in Nepal, with a Particular Focus on Tractors and Combine Harvesters," IFPRI Discussion Paper 01662, International Food Policy Research Institute, Washington, DC.

Takeshima, H., and L. Nagarajan. 2012. "Minor Millets in Tamil Nadu, India: Local Market Participation, On-Farm Diversity and Farmer Welfare.” Environment and Development Economics 17 (5): 603-632.

Toufique, K., and B. Belton. 2014. "Is Aquaculture Pro-Poor? Empirical Evidence of Impacts on Fish Consumption in Bangladesh." World Development 64: 609-620.

Upadhyaya, H., K. Otsuka, and C. C. David. 1990. "Differential Adoption of Modern Rice Technology and Regional Wage Differential in Nepal." Journal of Development Studies 26 (3): 450-468.

USDA (United States Department of Agriculture). 2020. Economic Research Service Agricultural Productivity Project. Accessed June 8. https://www.ers.usda.gov/data-products/international -agricultural-productivity/.

Weinberger, K., and T. A. Lumpkin. 2007. "Diversification into Horticulture and Poverty Reduction: A Research Agenda.” World Development 35 (8): 1464-1480.

World Bank. 2017. Data. Accessed November 15, 2017. http://data.worldbank.org/.

_.2018. World Development Indicators database. Accessed 2018. http://wdi.org.

Zhang, X., and S. Fan. 2004. "How Productive Is Infrastructure? A New Approach and Evidence from Rural India." American Journal of Agricultural Economics 86 (2): 492-501. 